\title{
Atmospheric mercury speciation dynamics at the high-altitude Pic du Midi Observatory, southern France
}

\author{
Xuewu Fu ${ }^{1,2}$, Nicolas Marusczak ${ }^{1}$, Lars-Eric Heimbürger ${ }^{1,3}$, Bastien Sauvage ${ }^{4}$, François Gheusi ${ }^{4}$, Eric M. Prestbo ${ }^{5}$, \\ and Jeroen E. Sonke ${ }^{1}$ \\ ${ }^{1}$ Observatoire Midi-Pyrénées, Laboratoire Géosciences Environnement Toulouse, CNRS/IRD/Université de Toulouse, \\ 14, Avenue Édouard Belin, 31400 Toulouse, France \\ ${ }^{2}$ State Key Laboratory of Environmental Geochemistry, Institute of Geochemistry, Chinese Academy of Sciences, \\ 46 Guanshui Road, 550002 Guiyang, China \\ ${ }^{3}$ Mediterranean Institute of Oceanography, Campus de Luminy,13288 Marseille, France \\ ${ }^{4}$ Observatoire Midi-Pyrénées, Laboratoire d'Aérologie, CNRS/IRD/Université de Toulouse, 14, Avenue Édouard Belin, \\ 31400 Toulouse, France \\ ${ }^{5}$ Tekran Research and Development, 330 Nantucket Blvd., Toronto, ON, M1P2P4, Canada
}

Correspondence to: Xuewu Fu (fuxuewu@mail.gyig.ac.cn) and Jeroen E. Sonke (jeroen.sonke@get.obs-mip.fr)

Received: 17 October 2015 - Published in Atmos. Chem. Phys. Discuss.: 2 February 2016

Revised: 6 April 2016 - Accepted: 20 April 2016 - Published: 4 May 2016

\begin{abstract}
Continuous measurements of atmospheric gaseous elemental mercury (GEM), particulate bound mercury (PBM) and gaseous oxidized mercury (GOM) at the high-altitude Pic du Midi Observatory (PDM Observatory, $2877 \mathrm{~m}$ a.s.1.) in southern France were made from November 2011 to November 2012. The mean GEM, PBM and GOM concentrations were $1.86 \mathrm{ng} \mathrm{m}^{-3}, 14 \mathrm{pg} \mathrm{m}^{-3}$ and $27 \mathrm{pg} \mathrm{m}^{-3}$, respectively and we observed 44 high PBM (peak PBM values of 33-98 $\mathrm{pg} \mathrm{m}^{-3}$ ) and 61 high GOM (peak GOM values of 91-295 $\mathrm{pg} \mathrm{m}^{-3}$ ) events. The high PBM events occurred mainly in cold seasons (winter and spring) whereas high GOM events were mainly observed in the warm seasons (summer and autumn). In cold seasons the maximum air mass residence times (ARTs) associated with high PBM events were observed in the upper troposphere over North America. The ratios of high PBM ARTs to total ARTs over North America, Europe, the Arctic region and Atlantic Ocean were all elevated in the cold season compared to the warm season, indicating that the middle and upper free troposphere of the Northern Hemisphere may be more enriched in PBM in cold seasons. PBM concentrations and PBM / GOM ratios during the high PBM events were significantly anticorrelated with atmospheric aerosol concentrations, air temperature and solar radiation, suggesting in situ formation of PBM in the middle and upper troposphere. We identi-
\end{abstract}

fied two distinct types of high GOM events with the GOM concentrations positively and negatively correlated with atmospheric ozone concentrations, respectively. High GOM events positively correlated with ozone were mainly related to air masses from the upper troposphere over the Arctic region and middle troposphere over the temperate North Atlantic Ocean, whereas high GOM events anti-correlated with ozone were mainly related to air masses from the lower free troposphere over the subtropical North Atlantic Ocean. The ARTs analysis demonstrates that the lower and middle free troposphere over the North Atlantic Ocean was the largest source region of atmospheric GOM at the PDM Observatory. The ratios of high GOM ARTs to total ARTs over the subtropical North Atlantic Ocean in summer were significantly higher than those over the temperate and sub-arctic North Atlantic Ocean as well as that over the North Atlantic Ocean in other seasons, indicating abundant in situ oxidation of GEM to GOM in the lower free troposphere over the subtropical North Atlantic Ocean in summer. 


\section{Introduction}

Transformations of mercury $(\mathrm{Hg})$ in the atmosphere play a crucial role in the global Hg cycle (Selin et al., 2007; Driscoll et al., 2013). Gaseous elemental mercury (GEM) is the predominant form emitted by anthropogenic and natural sources (Pirrone et al., 2010). GEM is then transformed to gaseous oxidized mercury (GOM) and particulate bound mercury (PBM) by oxidation. Atmospheric Hg deposition occurs by wet deposition and dry deposition pathways. Models suggest global GEM dry deposition to be potentially important, yet lack broad observational evidence (Selin et al., 2008). On the other hand, GOM and PBM are readily scavenged from the atmosphere by wet deposition and dry deposition pathways. Due to its fast dry deposition velocities, GOM is thought to be mainly scavenged from the atmosphere by dry deposition, whereas wet deposition plays a more important role in the removal of PBM in the atmosphere (Lee et al., 2001; Zhang et al., 2009; Lin et al., 2010). Hence, conversion of GEM to GOM and PBM is a crucial process in the removal of $\mathrm{Hg}$ in the atmosphere, which in turn affects the loading of $\mathrm{Hg}$ to terrestrial and marine ecosystems.

Conversion of GEM to GOM and PBM is potentially occurring throughout the global atmosphere, but the rates of conversion are thought to vary and are dependent on the levels of atmospheric oxidants and environmental factors. Current modeling studies suggested that conversion of GEM to GOM and PBM produces approximately 8000 tons of GOM and PBM annually, which explains at least $90 \%$ of the total sources of GOM and PBM in the atmosphere (Holmes et al., 2010). However, it is still unclear where the majority of the conversion takes place, by what mechanism and which major oxidants and environmental factors are involved. Over the last decade, studies have been carried out to measure atmospheric $\mathrm{Hg}$ speciation at high-altitude sites in the USA and Asia and on research flights. A study at the Mount Bachelor observatory (MBO, USA) showed elevated GOM (up to $600 \mathrm{pg} \mathrm{m}^{-3}$ ) and low GEM in the free troposphere, suggesting in situ oxidation (Swartzendruber et al., 2006). Observations at Storm Peak laboratory (SPL, USA) and Lulin Atmospheric Background Station (LABS, Taiwan) showed similar, though less elevated, GOM events in free tropospheric air masses (Fain et al., 2009; Sheu et al., 2010). Long-term $\mathrm{Hg}$ speciation observations at MBO suggest GEM oxidation to be enhanced in long-range Asian pollution plumes, but also in marine boundary layer (MBL) air masses originating over the Pacific Ocean (Timonen et al., 2013). INTEX$\mathrm{B}$ in-flight observations of GEM in the tropopause region $(8-12 \mathrm{~km})$ have shown low GEM levels, sometimes down to zero, indicative of rapid oxidation (Talbot et al., 2007). CARIBIC in-flight observations of total gaseous Hg (TGM $\sim$ GEM+GOM) showed lower TGM levels in the southern hemisphere, TGM depletion in the extratropical lowermost stratosphere and a general negative correlation between TGM and ozone (Slemr et al., 2009, 2014). In-flight, in situ analyses of stratospheric aerosols suggest that the upper troposphere and lower stratosphere depletion in GEM is balanced by abundant PBM (Murphy et al., 1998, 2006). Recent in-flight measurements provided the first simultaneous observations of both GEM and the combined GOM+PBM fractions at an altitude above $6 \mathrm{~km}$ (Lyman and Jaffe, 2012). The study showed elevated GOM+PBM levels in stratospheric air masses and confirmed the importance of stratospheric GEM oxidation. The findings of all these studies indicate that the free troposphere and lower stratosphere are important regions for conversion of GEM to GOM and PBM.

A recent study reviewed mountain-top studies of free troposphere $\mathrm{Hg}$ dynamics and compared observations to the GEOS-Chem atmospheric Hg chemistry and transport model (Weiss-Penzias et al., 2015). The model intercompared $\mathrm{Hg}$ oxidation by $\mathrm{Br}$ against $\mathrm{OH}$-ozone pathways and was able to only marginally reproduce observations, indicating the need to improve both measurement techniques and models. Additional long-term observations of GEM, GOM, and PBM are therefore necessary to map out regions and altitudes that favor GEM oxidation, and provide insight into the oxidation mechanisms. In the present study, we carried out 1 year of continuous measurements of speciated atmospheric mercury at the Pic du Midi (PDM) Observatory, a high-altitude site (2877 m a.s.1.) in the French Pyrenees mountains. This is the first year-around study of atmospheric $\mathrm{Hg}$ speciation at a mid-latitude high-altitude site. This study may help to better understand the seasonal patterns of high GOM and PBM events and the mechanisms underlying the transformations of atmospheric $\mathrm{Hg}$ in the free troposphere over the lower, middle and high latitudes.

\section{Materials and methods}

\subsection{Site description}

The Pic du Midi (PDM) Observatory $\left(0.142^{\circ} \mathrm{E}, 42.937^{\circ} \mathrm{N}\right.$, $2877 \mathrm{~m}$ a.s.l.) is a high-altitude monitoring station situated on top of an isolated peak (elevated approximately $1300 \mathrm{~m}$ relative to the surrounding terrain) on the northern edge of the central Pyrenees mountains, southwest France. It is approximately $150 \mathrm{~km}$ to the east of the North Atlantic coast and $210 \mathrm{~km}$ to west of the Mediterranean Sea. The PDM Observatory frequently receives free tropospheric air from the North Atlantic and Europe (Henne et al., 2010). The station may also be partly influenced by boundary layer air transported by plain-to-mountain winds from southwest France or through regional transport from Spain under southerly or south-westerly synoptic wind conditions (Gheusi et al., 2011; Tsamalis et al., 2014). There are no point sources around the station or in the surrounding areas. The two nearest cities are Pau and Tarbes which are respectively located 60 and $30 \mathrm{~km}$ northwest to the station and may influence the observations via upslope transport. 


\subsection{Measurements of speciated atmospheric mercury and ancillary parameters}

Speciated atmospheric $\mathrm{Hg}$ is continuously measured at the PDM Observatory using the Tekran 2537/1130/1135 system (Tekran Inc., Canada). The period analyzed in this study goes from 18 November 2011 to 17 November 2012. The Tekran system has been widely used and described in detail elsewhere (Landis et al., 2002; Lindberg et al., 2002). Briefly, GOM, PBM, and GEM in ambient air were collected onto $\mathrm{KCl}$-coated annular denuder, regenerable quartz fiber filter and dual gold cartridges in sequence. The system was programmed to collect GOM and PBM at $1 \mathrm{~h}$ intervals at a volumetric flow rate of $10 \mathrm{~L} \mathrm{~min}^{-1}$; and GEM was collected at $5 \mathrm{~min}$ intervals at a volumetric flow rate of $1.07 \mathrm{~L} \mathrm{~min}^{-1}$. Once collected, $\mathrm{Hg}$ is thermally decomposed from each unit and detected by cold vapor atomic fluorescence spectroscopy (CVAFS) as $\mathrm{Hg}^{0}$. GEM concentrations were directly measured by the Tekran 2537 Analyzer. Recent studies have suggested that the biased integration of small mercury loads (e.g. < 10 pg) may lead to a low bias of GOM and PBM concentrations (Slemr et al., 2016; Swartzendruber et al., 2009). In this study, final GOM and PBM concentrations were calculated following the method proposed by the Atmospheric Mercury Network (AMNet) quality control (Steffen et al., 2012). Concentrations of GEM are expressed in $\mathrm{ng} \mathrm{m}^{-3}$ (STP) and GOM and PBM are expressed in $\mathrm{pg} \mathrm{m}^{-3}$ (STP) with standard temperature of $273.14 \mathrm{~K}$ and pressure of $1013 \mathrm{hPa}$. KCl-coated denuder, Teflon coated glass inlet, and impactor plate were replaced bi-weekly and quartz filters were replaced monthly. Denuders and quartz filters were prepared and cleaned before field sampling following the methods in Tekran technical notes. The Tekran 2537B analyzer was routinely calibrated using its internal permeation source at a $47 \mathrm{~h}$ interval, and was also cross-calibrated every 3 months against an external temperature controlled $\mathrm{Hg}$ vapor standard. Due to the frequent extreme weather conditions at the PDM Observatory, the system was installed inside a temperature-controlled laboratory. Ambient air was introduced into the Tekran unit using the Tekran 1004 Teflon coated manifold, which is similar as that used at the MBO, USA (Swartzendruber et al., 2006). The inlet of the Tekran 1104 manifold was about $0.5 \mathrm{~m}$ from the outside wall of the laboratory and oriented to the southwest (the local predominant wind direction) of the laboratory. Temperature of the Tekran 1104 manifold was kept at $70^{\circ} \mathrm{C}$ and air flow through the manifold was about $100 \mathrm{~L} \mathrm{~min}^{-1}$. Blanks of Tekran unit and manifold were quantified at the beginning and end of each maintenance (bi-weekly) using Hg-free ambient air. The annual mean GEM blank of the Tekran unit was $0.04 \pm 0.03 \mathrm{ng} \mathrm{m}^{-3}(1 \mathrm{SD})$ and detection limit of GEM was estimated to be $0.1 \mathrm{ng} \mathrm{m}^{-3}$.

Measurement of GOM and PBM is challenging due to the typical low part per quadrillion (ppq) concentrations, reactivity and potential for species interconversion, and the need to pre-concentrating on a surface. In addition the lack of understanding of the specific forms and accepted calibration standards of GOM and PBM hinders the ability to obtain infield quality assurance measurements, like dynamic spiking under changing atmospheric conditions. Recently, uncertainties regarding the accuracy of GOM measurements have been discovered related to $\mathrm{O}_{3}$ and water vapor levels suggesting a potential for low GOM bias under certain atmospheric conditions (Lyman et al., 2010; Gustin et al., 2013). Another study suggested that GOM concentrations measured by cation exchange membranes were 1.3 to 3.7 times higher than that measured by $\mathrm{KCl}$-coated denuders, but was only a comparison of two differing methods, with neither one challenged in real time by standard spiking under atmospheric conditions (Huang et al., 2013). On the other hand, the potential for the PBM to be biased has not been thoroughly studied and understood, for the reasons mentioned above, however the bias would likely be positive due to GEM uptake as the regenerable filter ages and becomes more reactive. At the PDM Observatory, similar to other high-altitude studies, we do not observe simultaneous increases of PBM during high GOM events suggesting no significant GOM breakthrough or GEM uptake on the filter (Malcolm and Keeler, 2007; Swartzendruber et al., 2006; Fain et al., 2009). Similarly GOM loss from denuders has been suggested to relate to high humidity levels (McClure et al., 2014). The elevated free tropospheric PBM and GOM events discussed in this study occur predominantly in low humidity air masses (median humidity of 21 and $28 \%$ respectively) limiting GOM losses. Therefore, as most of the discussion in the present study is based on the relative variations of GOM and PBM, we assume the potential sampling artifacts may bring a minimal uncertainty to the overall findings. Most importantly, the method used in this study and others is "state of the art" at this time and has resulted in profound discoveries that are scientifically coherent (Schroeder and Munthe, 1998; Laurier et al., 2003; Lindberg et al., 2002; Swartzendruber et al., 2006; Steffen et al., 2008; Sprovieri et al., 2010; Fu et al., 2015). Currently, there is no better method to routinely separate and quantify low, partper-quadrillion concentrations of the mercury fractions with hourly time resolution, than the use of a fully heated sample train that rejects large particles ( $>2.5 \mu \mathrm{m}$ ) by impaction, capture of "sticky" GOM species on a laminar flow, coated annular denuder, which rejects both PBM and GEM, followed by a quartz fiber filter to collect PBM, which rejects GEM so it can pass to a sensitive monitor for continuous detection. The operationally defined method to quantify atmospheric mercury fractions is similar to well established methods used for other "sticky gases" ammonia and nitric acid.

Atmospheric CO and ozone concentrations were continuously measured using the TEI 48CTL gas filter correlation analyzers and 49C Ozone analyzer (Thermo Environmental Instruments Inc. USA), respectively. Detailed information regarding the principle of the instruments, calibrations, and measurement uncertainties can be found in a previous 
study (Gheusi et al., 2011). The standard uncertainties associated with $\mathrm{CO}$ and ozone data sets ( $15 \mathrm{~min}$ averaged data) were reported to be 6.6 and $1.2 \mathrm{ppbv}$, respectively (Gheusi et al., 2011). Atmospheric aerosol number concentration in $\mathrm{PM}_{10}$ particles (i.e. of diameter $<10 \mu \mathrm{m}$ ) was measured at the PDM Observatory using a condensation particle counter (CPC), Model 3010 by TSI Inc. The particles are detected by condensing butanol vapor onto the particles, causing them to grow into droplets. These particles (in the droplet form) are then counted by optical absorption (Gheusi et al., 2011). $\mathrm{CO}$ and ozone mole fractions, as well as atmospheric aerosol number concentration and standard meteorological variables at the PDM Observatory were obtained as $5 \mathrm{~min}$ averages from the PAES (French acronym for atmospheric pollution at synoptic scale; http://paes.aero.obs-mip.fr/) network.

\subsection{Simulations of back trajectories, air masses residence times and potential source regions}

In the present study, we calculated 10-day back normal trajectory for high PBM events and 7-day back normal trajectory for high GOM events, respectively using the NOAA Hysplit trajectory model and gridded meteorological data (Global Data Assimilation System, GDAS1; Rolph, 2016), which are close to the upper range of the lifetime of GOM and PBM in the atmosphere (Schroeder and Munthe, 1998; Driscoll et al., 2013). The GDAS1 has a horizontal resolution of 1 degree $(360 \times 180$ grid cells $)$ with 23 vertical levels from $1000 \mathrm{hPa}$ to $20 \mathrm{hPa}$. The trajectories ended at the PDM Observatory at a height of $3000 \mathrm{~m}$ a.s.l. (approximately $100 \mathrm{~m}$ above the sampling site). In addition, we also used the Flexpart Lagrangian particle dispersion model version 9.0 (Stohl et al., 2005) to simulate the 20 days back trajectories for two special events (high PBM event \#12 and \#19) and to make a comparison with Hysplit. The Flexpart model is driven by wind fields provided by the European Centre for Medium-Range Weather Forecast (ECMWF) with a temporal resolution of $3 \mathrm{~h}$ (analyses at 00:00, 06:00, 12:00, 18:00 UTC; forecasts at 03:00, 09:00, 15:00, 21:00 UTC) and with horizontal resolution of $32 \mathrm{k} \mathrm{m}$. The model output refers to the time, in seconds, the released particles spent in each output grid box before reaching the PDM Observatory. Flexpart residence times are output every $3 \mathrm{~h}$ on a uniform grid of $0.5^{\circ}$ latitude $\times 0.5^{\circ}$ longitude in 40 vertical layers from mean sea level to a height of $20 \mathrm{~km}$ above sea level. In the present study, we analyzed how air masses from different sublayers in the troposphere affect atmospheric PBM and GOM concentrations at the PDM Observatory. We subdivide the troposphere into four sublayers: boundary layer $(>900 \mathrm{hPa})$, lower free troposphere $(700-900 \mathrm{hPa})$, middle free troposphere (500-700 hPa) and upper free troposphere (200-500 hPa).

Air mass residence times (ARTs) were calculated on the basis of the simulations of 7-day backward trajectories ending at the PDM Observatory. The studied domain covered by the trajectories was divided into 3590 grid cells of $2.5^{\circ}$ latitude $\times 2.5^{\circ}$ longitude. To reduce the "central convergence" effect and highlight the long-range transport processes (Cuevas et al., 2013), we adjusted the residence times using the geometric adjustment factor as proposed by Poirot and Wishinski (1986).

The potential source regions of PBM and GOM were simulated using a Potential Source Contribution Function (PSCF) approach (Zeng and Hopke, 1989). The PSCF value indicates the probability that a source area contributed to the receptor site and is defined as

$\mathrm{PSCF}_{i j}=\frac{M_{i j}}{N_{i j}} \times W_{i j}$.

$M_{i j}$ is the total number of trajectory segment endpoints (Each trajectory segment endpoint represents the estimated position of the air mass every $1 \mathrm{~h}$ back in time from the receptor) in a grid cell associated to PBM and GOM concentrations at the PDM Observatory higher than the annual means, $N_{i j}$ is the total number of trajectory segment endpoints in a grid cell, and $W_{i j}$ is a weighting function used to minimize the uncertainties of a small $N_{i j}$ and described by Polissar et al. (2001). For the PBM and GOM PSCF analysis, 7-day back trajectories ending at the PDM Observatory were calculated every $2 \mathrm{~h}$ throughout the whole study period. The total trajectory endpoints in the boundary layer, lower free troposphere, and middle and upper troposphere in the studied domain were 152025,285726 , and 250557 , respectively. The studied domain was divided into 5566 grid cells of $2.0^{\circ}$ latitude $\times 2.0^{\circ}$ longitude. Areas with high PSCF values are likely enriched in atmospheric PBM and GOM and probably contribute to the elevated PBM and GOM concentrations at the PDM Observatory. We caution, due to the trajectory innate spatial uncertainty, meteorological parameters (e.g. precipitation, humidity), "trailing effect", etc, that PSCF analysis could have some uncertainties in identification of source regions (Engstrom and Magnusson, 2009; Cheng et al., 2015). In this study, these factors were not evaluated and therefore the identified source regions of GOM and PBM by PSCF analysis should be regarded as a qualitative indication.

\section{Results and discussion}

\subsection{Annual, seasonal, and diel trends}

Averaged atmospheric GEM, PBM, and GOM concentrations at the PDM Observatory during the study period were $1.86 \pm 0.27 \mathrm{ng} \mathrm{m}^{-3}, 14 \pm 10 \mathrm{pg} \mathrm{m}^{-3}$, and $27 \pm 34 \mathrm{pg} \mathrm{m}^{-3}$, respectively (time series of GEM, PBM and GOM concentrations are in Fig. S1 in the Supplement). The level of GEM at the PDM Observatory was slightly higher than the previous observations at remote sites in Europe (means: 1.66$1.82 \mathrm{ng} \mathrm{m}^{-3}$; Slemr and Scheel, 1998; Lee et al., 1998; Kock et al., 2005) and North America (means: $1.32-1.72 \mathrm{ng} \mathrm{m}^{-3}$; 


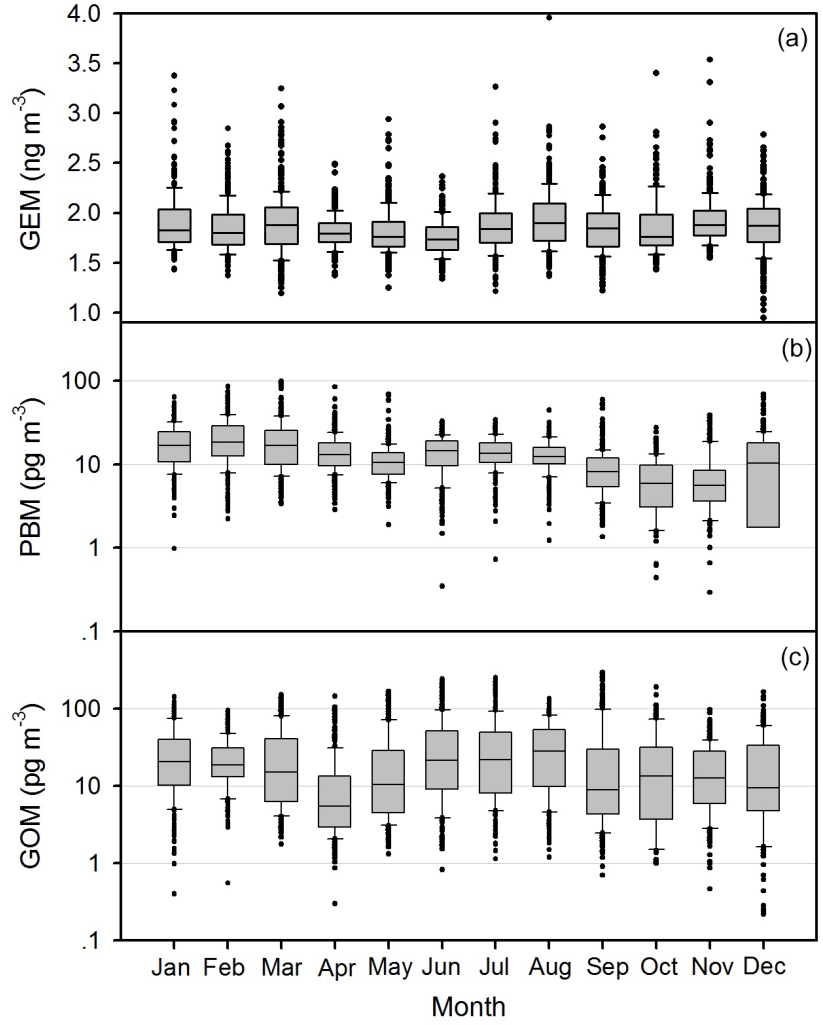

Figure 1. Monthly variation of atmospheric GEM (a), PBM (b), and GOM (c) at the PDM Observatory. Box lines indicate the 10th, 25th, 50th, 75th, 90th percentiles, and data points indicate concentrations below 10th and above 90th percentiles.

Kellerhals et al., 2003; Lan et al., 2012), but lower than that observed in Asia (means: $1.60-3.98 \mathrm{ng} \mathrm{m}^{-3}$; Fu et al., 2015). Continuous measurements of atmospheric $\mathrm{Hg}$ speciation at high-altitude sites are limited worldwide. The mean PBM concentration at the PDM Observatory was approximately 7 times higher than at LABS $\left(2 \mathrm{pg} \mathrm{m}^{-3}, 23.5^{\circ} \mathrm{N}\right.$, $2862 \mathrm{~m}$ a.s.l.; Sheu et al., 2010), and also higher than the summertime means at SPL $\left(9 \mathrm{pg} \mathrm{m}^{-3}, 40.5^{\circ} \mathrm{N}, 3230 \mathrm{~m}\right.$ a.s.l. $)$ and MBO $\left(5 \mathrm{pg} \mathrm{m}^{-3}, 44.0^{\circ} \mathrm{N}, 2700 \mathrm{~m}\right.$ a.s.l.; Swartzendruber et al., 2006; Fain et al., 2009). The annual mean GOM concentration at the PDM Observatory was relatively higher than at LABS (annual mean: $12 \mathrm{pg} \mathrm{m}^{-3}$ ) and SPL (summertime mean: $20 \mathrm{pg} \mathrm{m}^{-3}$; Fain et al., 2009; Sheu et al., 2010), but lower than at MBO (summertime mean: $40 \mathrm{pg} \mathrm{m}^{-3}$; Swartzendruber et al., 2006). The difference in atmospheric PBM and GOM concentrations among high-altitude sites may partially reflect measurements uncertainty, but also be due to the different regional and long-range $\mathrm{Hg}$ transport, atmospheric $\mathrm{Hg}$ transformations, and intrusions of air from the upper troposphere and lower stratosphere.

Differences in GEM concentrations for different seasons were not statistically significant ( $t$ test $p=0.73$, Fig. 1$)$. The monthly mean PBM concentrations were relatively higher

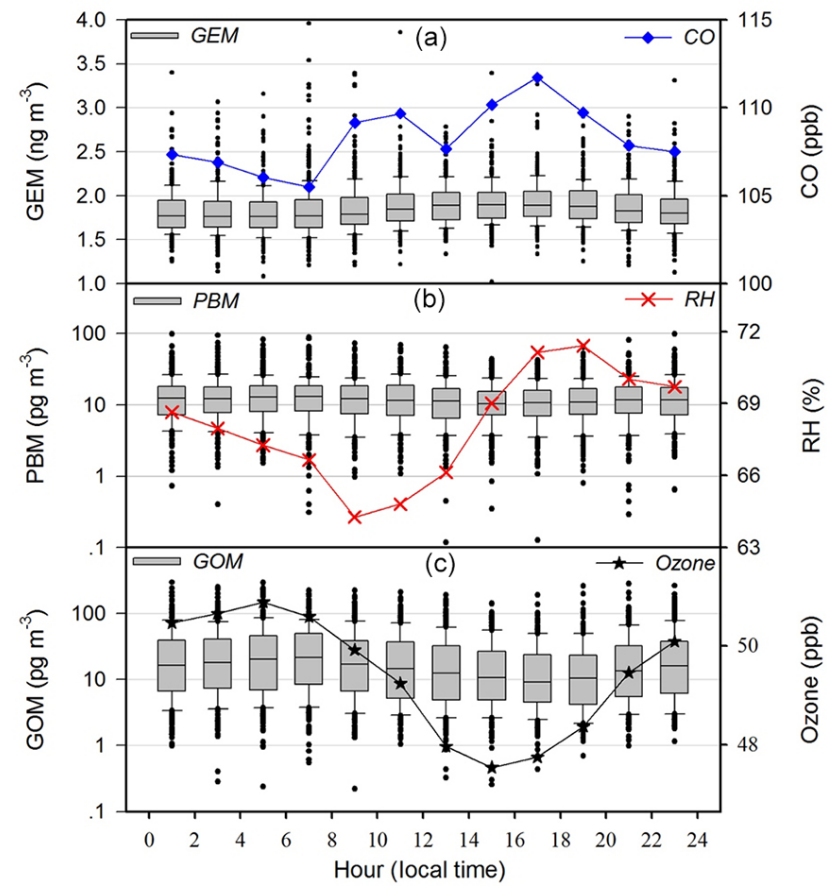

Figure 2. Diel, $2 \mathrm{~h}$ averaged, variations of atmospheric GEM and $\mathrm{CO}$ (a); PBM and relative humidity (RH; b); and GOM and ozone (c) at the PDM Observatory. Box lines indicate the 10th, 25th, 50th, 75th, 90th percentiles, and data points indicate concentrations below 10th and above 90th percentiles.

$(p<0.05)$ in winter (December to February) and spring (March to May) than in summer (June to August) and autumn (September to November), with the highest monthly mean of $21 \mathrm{pg} \mathrm{m}^{-3}$ in February and the lowest monthly mean of $7 \mathrm{pg} \mathrm{m}^{-3}$ in October. This seasonal pattern is similar to the observations at LABS as well as low-altitude sites in North America and China (Lan et al., 2012; Fu et al., 2012; Sheu et al., 2010). Elevated winter PBM concentrations are common at low-altitude sites in the Northern Hemisphere, which is likely linked to emissions from residential heating, and low temperature facilitating gas-particle partitioning of atmospheric mercury, and decreasing wet scavenging processes (Lan et al., 2012; Rutter and Schauer, 2007; Selin et al., 2007). Monthly mean GOM concentrations were relatively higher $(p<0.05)$ in summer (mean: $38 \mathrm{pg} \mathrm{m}^{-3}$ ), followed by winter (mean: $25 \mathrm{pg} \mathrm{m}^{-3}$ ), autumn (mean: $25 \mathrm{pg} \mathrm{m}^{-3}$ ), and spring (mean: $23 \mathrm{pg} \mathrm{m}^{-3}$; Fig. 1). In general, in situ oxidation of GEM and long-range transport of GOM-enriched air from the free troposphere, rather than anthropogenic emissions are the dominant sources of atmospheric GOM at highaltitude sites (Sheu et al., 2010; Swartzendruber et al., 2006; Fain et al., 2009). The summer maximum GOM at the PDM Observatory may indicate these processes are more dominant in summer than during other seasons.

Atmospheric GEM, PBM, and GOM displayed welldefined diel trends at the PDM Observatory (Fig. 2). GEM 


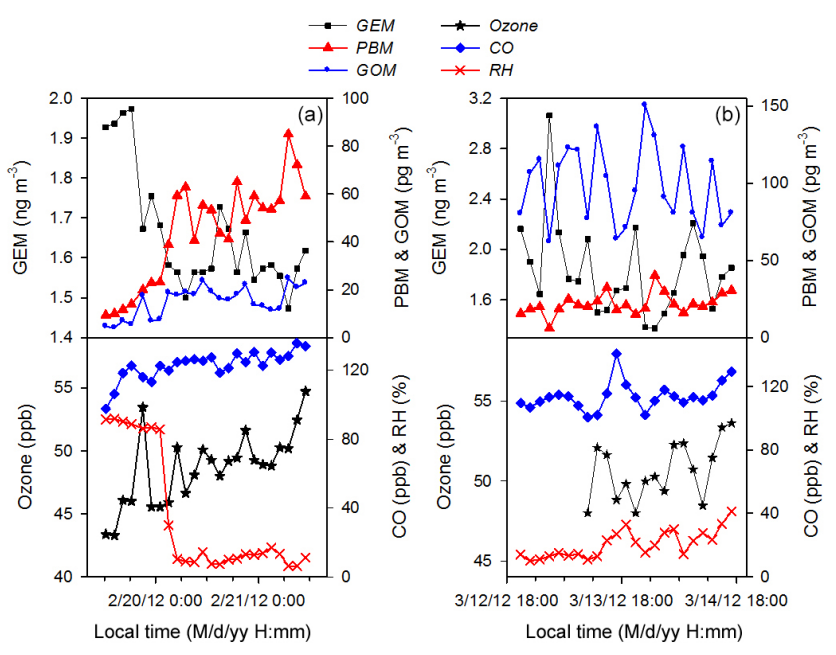

Figure 3. Time series of GEM, PBM, GOM, ozone, CO, and relative humidity (RH) during high PBM event \#12 (a) and \#19 (b).

concentrations ( $2 \mathrm{~h}$ means) were relatively higher during daytime with the maximum observed in the later afternoon (around 17:00) and minimum observed in the early morning (around 05:00), and positively correlated with CO $\left(r^{2}=0.70, p<0.01\right)$. The diel trends in PBM and GOM contrast with that of GEM, with the maximum PBM and GOM concentrations ( $2 \mathrm{~h}$ means) observed in the early morning (around 07:00) and the minimum concentrations in the later afternoon (around 17:00; Fig. 2). PBM and GOM concentrations were significantly anti-correlated with GEM concentrations $\left(r_{\text {GEM-PBM }}^{2}=0.91, r_{\text {GEM-PBM }}^{2}=0.87, p<0.01\right.$ for both $)$ and $\mathrm{CO}$ concentrations $\left(r_{\mathrm{GEM}-\mathrm{PBM}}^{2}=0.74, r_{\mathrm{GEM}-\mathrm{PBM}}^{2}=0.75\right.$, $p<0.01$ for both), and positively correlated with each other $\left(r_{\mathrm{GOM}-\mathrm{PBM}}^{2}=0.91, p<0.01\right)$ and with ozone concentrations $\left(r_{\text {ozone-PBM }}^{2}=0.93, r_{\text {ozone-GOM }}^{2}=0.88, p<0.01\right.$ for both $)$. The diel trends of atmospheric $\mathrm{Hg}$ species at the PDM Observatory were similar to those at MBO and LABS (Sheu et al., 2010; Swartzendruber et al., 2006), but in contrast with the GOM diel trend at SPL which showed relatively higher values in the afternoon (Fain et al., 2009). The PDM Observatory is frequently impacted by upslope, valley, and plain-tomountain breezes (Gheusi et al., 2011; Tsamalis et al., 2014). Elevated GEM concentrations during daytime were likely related to upward transport of GEM enriched boundary layer air, whereas elevated PBM and GOM concentrations at night were attributed to long-range transport of PBM and GOMenriched air in the free troposphere (see below).

\subsection{High PBM events}

We observed 44 high PBM events, which were defined as the peak concentrations higher than $31 \mathrm{pg} \mathrm{m}^{-3}$, which are the 95th percentile PBM levels for the entire study. The maximum PBM concentration was $98 \mathrm{pg} \mathrm{m}^{-3}$, and was the highest value among the maximum PBM concentrations (33-
$40 \mathrm{pg} \mathrm{m}^{-3}$ ) observed at high-altitude sites (Sheu et al., 2010; Swartzendruber et al., 2006; Fain et al., 2009; Timonen et al., 2013).

For the 44 high PBM events, 30 events showed significant anti-correlations between PBM and GEM concentrations (Supplement Table S1). Also, the GEM levels during the 30 high PBM events when peak PBM concentrations were observed were generally low with concentrations less than the annual mean GEM concentrations of $1.86 \mathrm{ng} \mathrm{m}^{-3}$. This phenomenon is in contrast with PBM and GEM observations impacted by anthropogenic and biomass burning emissions which showed simultaneous increases of PBM and GEM concentrations (Manolopoulos et al., 2007; Song et al., 2009; Fu et al., 2011; Obrist et al., 2008). The air masses related to the 30 high PBM events mainly originated from the upper free troposphere over North America, Europe and the Arctic (Fig. S2). For the 30 high PBM events, 20 events had PBM / GOM ratios higher than 1, indicating a significant proportion of depleted GEM in the upper free troposphere was in the form of PBM rather than GOM. We acknowledge that PBM / GOM ratios may be affected by bias in denuder GOM measurements (Gustin et al., 2013). Nevertheless our observations on high PBM events appear different from previous studies at high-altitude sites (note that these studies were conducted in the warm season or in the tropics; Sheu et al., 2010; Swartzendruber et al., 2006; Fain et al., 2009). A possible explanation is that most of the high PBM events at the PDM Observatory were observed in the cold season which may favor the production and/or accumulation of PBM in the upper free troposphere.

Six out of the 44 PBM events (Table S1) were probably related to direct anthropogenic pollution. These events were accompanied by elevated GEM $\left(\right.$ mean $\left.=1.96 \pm 0.13 \mathrm{ng} \mathrm{m}^{-3}\right)$ and $\mathrm{CO}$ concentrations $(\mathrm{mean}=141 \pm 26 \mathrm{ppb})$ and low GOM concentrations $\left(\right.$ mean $\left.=22 \pm 15 \mathrm{pg} \mathrm{m}^{-3}\right)$. Also, the changes in PBM concentrations, in most cases, were positively correlated with GEM and $\mathrm{CO}$ and anti-correlated with GOM. The back trajectory analysis suggests that the air masses of these 6 PBM events were likely mixed with boundary layer air over Europe prior to ending at the PDM Observatory (Fig. S3). For the remaining eight high PBM events (Table S1), no significant correlations were observed between PBM concentrations and GEM. However, these events were generally accompanied by typical GEM (mean $=1.76 \pm 0.20 \mathrm{ng} \mathrm{m}^{-3}$ ) and CO (mean $=110 \pm 11 \mathrm{ppb)} \mathrm{concentrations,} \mathrm{low} \mathrm{relative} \mathrm{humidity}$ (mean $=33.0 \pm 24.1 \%$ ), and elevated GOM concentrations $\left(\right.$ mean $\left.=52 \pm 29 \mathrm{pg} \mathrm{m}^{-3}\right)$. Also, a significant positive correlation between PBM and GOM concentrations was observed for some of these events (Table S1). Therefore, these events were not likely related to direct anthropogenic pollution. The air masses related to these eight PBM events mainly originated from the middle free troposphere over the North Atlantic Ocean (Fig. S4). We therefore suggest that gas-particle partitioning of GOM in the middle free troposphere over the 

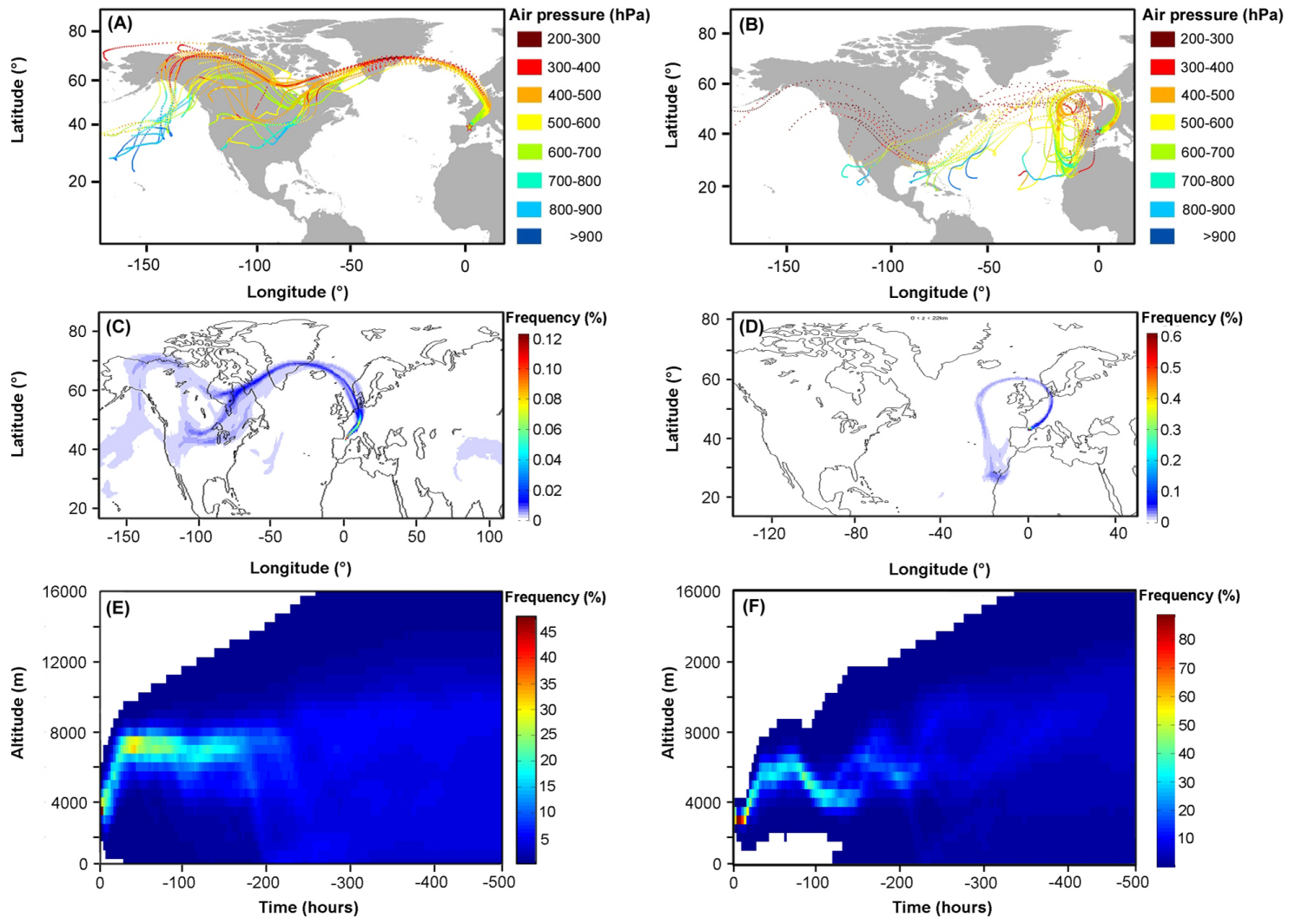

Figure 4. $240 \mathrm{~h}$ Hysplit air mass backward trajectories for the typical high PBM events \#12 (a) and \#19 (b), Flexpart simulated air mass source regions of high PBM events \#12 (c) and \#19 (d) and Flexpart simulated air mass traveling heights of PBM events \#12 (e) and \#19 (f). To reduce the uncertainty related to Hysplit trajectory simulations (Sexauer Gustin et al., 2012), Hysplit trajectories were calculated for each of the events ended at 27 locations evenly distributed in a $0.5^{\circ} \times 0.5^{\circ}$ grid cell and at a height of $-500,0$, and $500 \mathrm{~m}$ around the PDM Observatory.

North Atlantic Ocean and during long-range transport followed by mixing with European boundary layer air prior to ending at the PDM Observatory were the major cause for these eight high PBM events.

Figure 3 shows two typical PBM events (PBM events $\# 12$ and \#19 in Table S1) with PBM and GEM anticorrelated. During the PBM event \#12 (from 19 to 21 February 2012, Fig. 3a), the maximum PBM concentration reached up to $85 \mathrm{pg} \mathrm{m}^{-3}$, which was accompanied by low GEM $\left(1.47 \mathrm{ng} \mathrm{m}^{-3}\right)$, low GOM $\left(25 \mathrm{pg} \mathrm{m}^{-3}\right)$, low atmospheric aerosol number concentrations $\left(150 \mathrm{nbp} \mathrm{cm}^{-3}\right.$, Table $\mathrm{S} 1$ ), and low relative humidity (6\%) but elevated CO concentration (128 ppb). The maximum PBM concentration during PBM event \#19 was $40 \mathrm{pg} \mathrm{m}^{-3}$ (Fig. 3b), which is lower than that of PBM event \#12. PBM event \#19 showed elevated GOM concentrations (up to $131 \mathrm{pg} \mathrm{m}^{-3}$ ), higher atmospheric

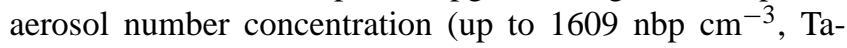
ble S1) but relatively lower CO concentrations (111 ppb; Table S1). Hysplit and Flexpart back trajectory analysis shows that the air masses related to the PBM event \#12 mainly originated from North America and passed over high-latitude areas in the upper free troposphere prior to ending at the PDM
Observatory (Fig. 4). PBM event \#19 originated mostly from middle and upper free troposphere over the Eastern North Atlantic Ocean and passed over western Europe in the middle and lower free troposphere before ending at the PDM Observatory (Fig. 4). We find good agreement between Hysplit and Flexpart in terms of air mass geographical origin and altitude over 10 days.

Gas-particle partitioning of GOM and heterogeneous oxidation of GEM at aerosols surfaces were suggested to be two important pathways for the formation of PBM in the atmosphere (Lindberg et al., 2002; Amos et al., 2012; Subir et al., 2012). For PBM event \#12, direct intrusion of PBMenriched air from the upper free troposphere likely played a dominant role. PBM event \#19 was likely related to gasparticle partitioning of GOM generated in the middle and upper free troposphere over the North Atlantic Ocean during the transport over Western Europe. The mechanisms and kinetics related to production of PBM are currently not well known. In the present study, we find that PBM concentrations and PBM / GOM ratios during all the events were both significantly anti-correlated with the atmospheric aerosol number concentrations ( $p<0.05$, Table S2). This result indicates 


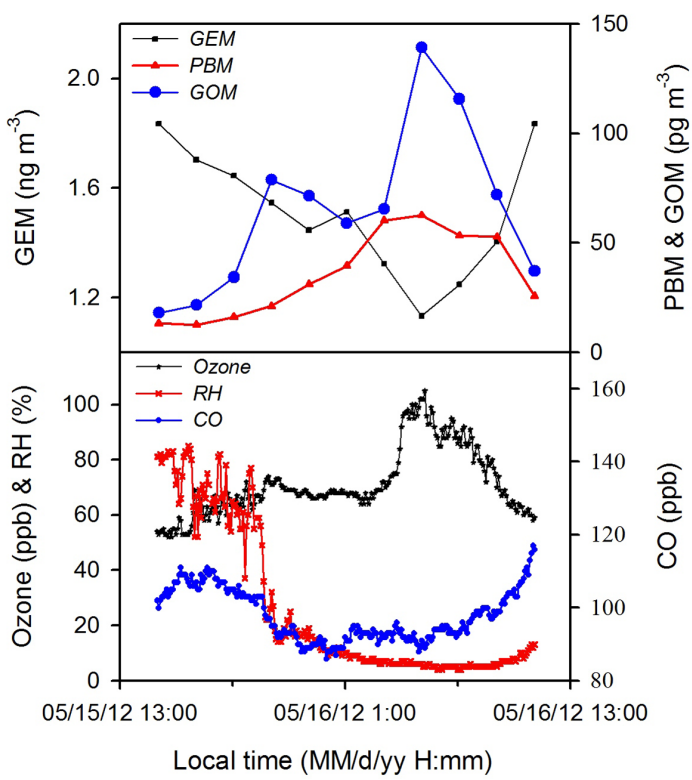

Figure 5. Time series of GEM, PBM, GOM, ozone, CO, and relative humidity $(\mathrm{RH})$ during high GOM event \#7.

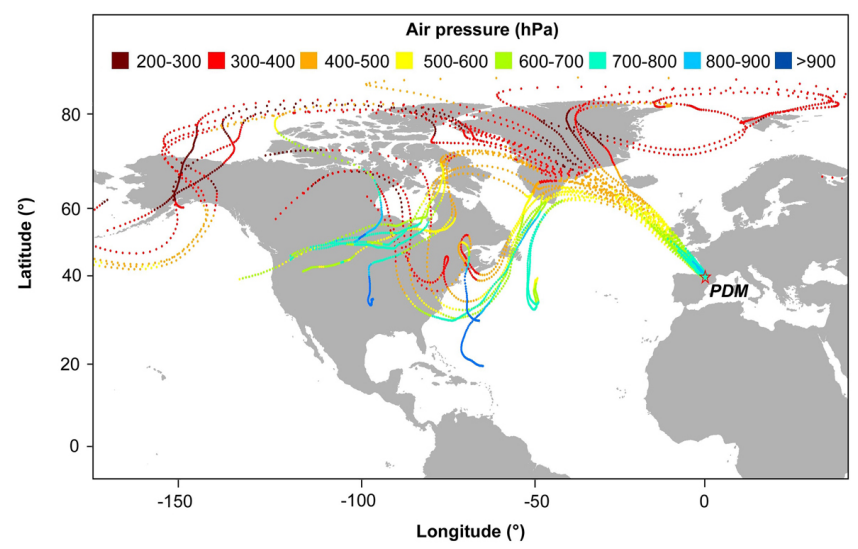

Figure 6. $168 \mathrm{~h}$ Hysplit air mass backward trajectories for the typical high GOM event \#7. To reduce the uncertainty related to trajectory simulations (Sexauer Gustin et al., 2012), trajectories were calculated for 27 locations evenly-distributed in a $0.5^{\circ} \times 0.5^{\circ}$ grid cell and at a height of $-500,0$, and $500 \mathrm{~m}$ around the PDM Observatory.

that concentrations of atmospheric aerosols may not play a dominant role in the formation of PBM in the middle and upper free troposphere and/or during the transport to the PDM Observatory, although atmospheric aerosol number concentrations observed at the PDM Observatory might be partially related to anthropogenic sources in the boundary layer and not representative of that in the middle and upper free troposphere. On the other hand, both PBM concentrations and PBM / GOM ratios during the high PBM events were significantly anti-correlated with simulated mean temperature of air masses ending at the PDM Observatory $(p<0.05$ for

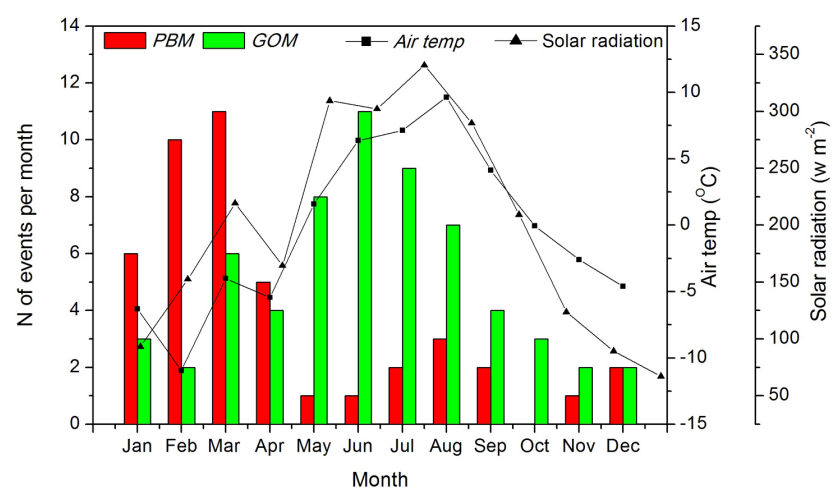

Figure 7. Monthly variations in the frequency of high PBM and GOM events at the PDM Observatory.

both, Table S2). Also, PBM / GOM ratios were found to be significantly anti-correlated with simulated mean solar radiation flux $(p<0.05$, Table S2). These results agree with previous studies which suggested that cold temperature and lower wintertime solar radiation enhance gas-particle partitioning of GOM and minimize the decomposition of PBM by photoreduction, respectively, which in turn facilitates the accumulation of PBM in the middle and upper free troposphere (Lindberg et al., 2002; Sprovieri et al., 2005; Rutter and Schauer, 2007; Amos et al., 2012). Previous studies also suggested that aerosol uptake of atmospheric oxidants and atmospheric GEM oxidation rates may be enhanced at cold temperature (Carslaw et al., 1997; Michelsen et al., 1999; Lindberg et al., 2007), which in turn facilitates the production of PBM via heterogeneous GEM oxidation and gas-particle partitioning of GOM.

\subsection{High GOM events}

High GOM events were identified as the concentrations higher than the 95 th percentile GOM level $\left(93 \mathrm{pg} \mathrm{m}^{-3}\right.$; Table S3). For the 61 high GOM events observed, 50 events were observed with a significant anti-correlation between GOM and GEM concentrations. Also, the remaining 11 high GOM events were not likely related to direct anthropogenic pollution because GEM, CO, and atmospheric aerosol number concentrations were not elevated and no positive correlations are observed between these parameters and GOM concentrations. We therefore conclude that the high GOM events at the PDM Observatory were primarily related to in situ oxidation of GEM, which is consistent with previous studies at high-altitude sites (Sheu et al., 2010; Swartzendruber et al., 2006; Fain et al., 2009).

In general, ozone, hydroxyl radical $(\mathrm{OH})$, nitrate radical (e.g. $\mathrm{NO}, \mathrm{NO}_{y}$ ), and reactive halogens (e.g. $\mathrm{Br}, \mathrm{BrO}, \mathrm{IO}$ ) are considered as potential oxidants involved in the conversion of GEM to GOM in the atmosphere (Lin and Pehkonen, 1999; Goodsite et al., 2004). However, the kinetics and relative contributions of these oxidants in the production of 

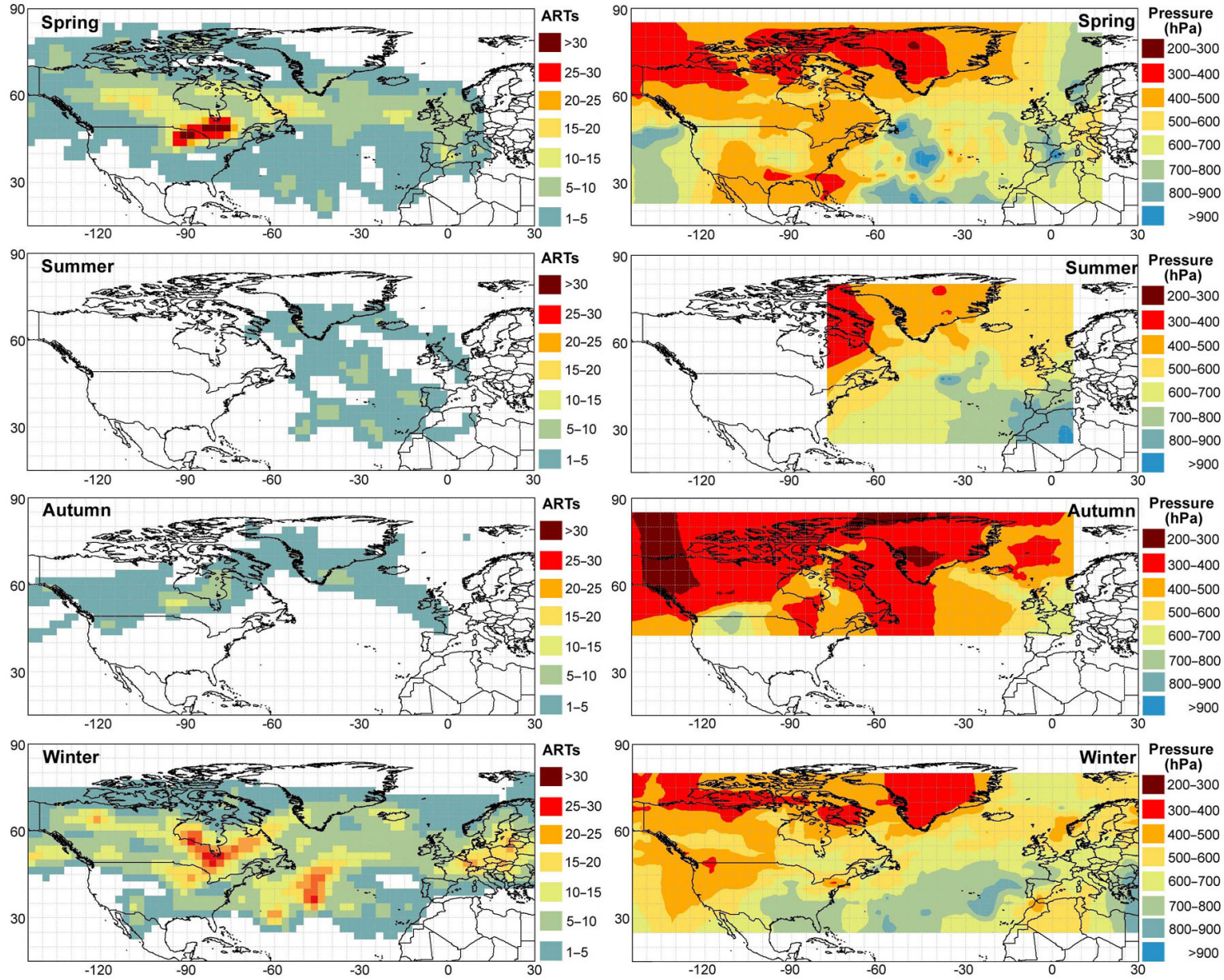

Figure 8. Air mass residence times (ARTs) and averaged pressure of air masses associated with high PBM events for each season during the study period.

atmospheric GOM are not well understood. In the present study, we observed that GOM and ozone concentrations were positively correlated during 24 high GOM events (Table S3). Meanwhile, hourly mean ozone concentrations associated with GOM peaks during the 24 high GOM events ranged from 41.4 to $98.5 \mathrm{ppb}$ with an average value of $62.5 \mathrm{ppb}$, and were relatively higher than the annual mean of $49.4 \mathrm{ppb}$. The most pronounced example was observed on 16 May 2012 (GOM Event \#7, Fig. 5). Clear positive correlations between GOM and ozone concentrations were also reported at MBO station, USA (Swartzendruber et al., 2006; Timonen et al., 2013), but elevated ozone concentrations as high as 105 ppb (5 min mean) during high GOM events \#7 were not observed in any previous observations at high-altitude sites. The highly elevated ozone concentrations as well as low $\mathrm{CO}$ concentrations and relative humidity demonstrate that event \#7 was mainly related to intrusions from the upper free troposphere. This assessment was further supported by the backward trajectory analysis which shows the major origins of air masses from the upper free troposphere over the Arctic region and North America (Fig. 6). At the night during event
\#7 when an upper tropospheric intrusion dominated, ozone concentrations were significantly anti-correlated with GEM $\left(\mathrm{GEM}=-9.3 \mathrm{pg} \mathrm{m}^{-3} \mathrm{ppb}^{-1} \times \mathrm{O}_{3} \mathrm{ppb}+2190 \mathrm{pg} \mathrm{m}^{-3}\right.$, $\left.r^{2}=0.72 p<0.01\right)$ and positively correlated with GOM concentrations $\quad\left(\mathrm{GOM}=2.69 \mathrm{pg} \mathrm{m}^{-3} \mathrm{ppb}^{-1} \times \mathrm{O}_{3} \mathrm{ppb}-\right.$ $\left.113 \mathrm{pg} \mathrm{m}^{-3}, r^{2}=0.96, p<0.01\right)$. The correlations indicated a total depletion of GEM in the upper free troposphere when ozone exceeds $235 \mathrm{ppb}$, and corresponding GOM concentrations up to approximately $520 \mathrm{pg} \mathrm{m}^{-3}$. This finding is in agreement with aircraft observations of GEM and $\mathrm{GOM}+\mathrm{PBM}$ fractions in the upper free troposphere and tropopause (Talbot et al., 2007; Lyman and Jaffe, 2012).

For the 24 high GOM events positively correlated with ozone, many air masses (10 out of the 24 high GOM events) originated from the upper troposphere over the Arctic region and the remainder from the middle troposphere over the North Atlantic Ocean (Fig. S5). This implies that the frequent southward intrusion of upper tropospheric air from the Arctic region may be an important source of high GOM levels at the PDM Observatory and mid-latitudes. In general, atmospheric ozone levels exhibit a clear vertical profile with concentra- 

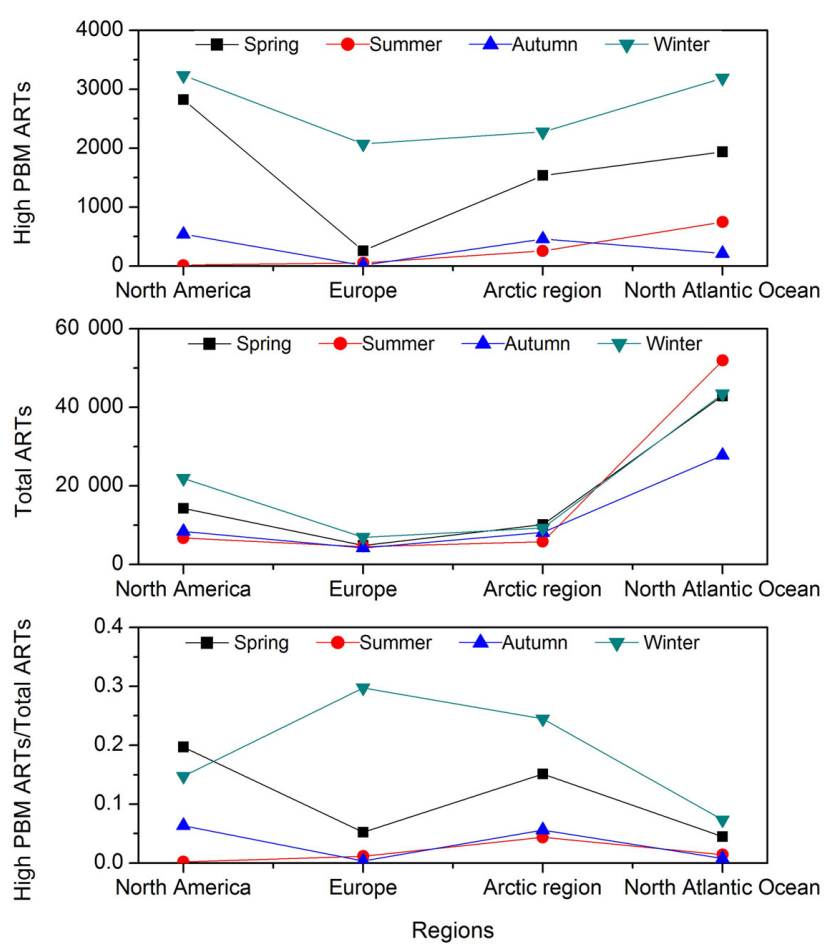

Figure 9. Seasonal variations in air masses residence times associated with high PBM events (high PBM ARTs, top), total residence times of all the air masses (Total ARTs, middle) and high PBM ARTs / Total ARTs ratios (bottom) in North America, Europe, Arctic region and North Atlantic Ocean.

tions increasing with altitude (Browell et al., 2003; Chevalier et al., 2007), and this may explain well the observed positive correlation between GOM and ozone concentrations. However, this by no means demonstrates that ozone is the exclusive oxidant during these events. In fact, nitrate radical (e.g. $\mathrm{NO}, \mathrm{NO}_{y}$ ) levels were found to be tightly correlated with ozone in the upper free troposphere (Gao et al., 2014; Kohler et al., 2013; Slemr et al., 2009). The vertical profiles of hydroxyl radical and reactive halogens are not well established (Brune et al., 1998). However, elevated $\mathrm{BrO}$ and $\mathrm{OH}$ levels were reported in the middle and upper free troposphere by previous studies (Brune et al., 1998; Fitzenberger et al., 2000). Therefore, these oxidants could also contribute to the oxidation of GEM in the middle and upper free troposphere.

Nine of the high GOM events showed anti-correlations between GOM and ozone concentrations (Table S3), which are in contrast with GOM events influenced by the middle and upper tropospheric air. Back trajectory analysis suggests that these events were influenced by air masses which originated from and/or passed over the North Atlantic in the lower free troposphere (Fig. S6). This type of event was similar to that observed in the Pacific Ocean MBL (Timonen et al., 2013; Laurier et al., 2003), indicating that a decrease in ozone concentration is a general feature of GOM production in lower free troposphere over oceans and MBL. It is possible that reactive halogen and hydroxyl radicals were involved in this type of GOM events, the formation of which in the MBL over oceans were thought to deplete atmospheric ozone (Bloss et al., 2003; Obrist et al., 2011; Read et al., 2008).

High GOM events were also reported to be related to oxidation of GEM in MBL over the Arctic region during Polar spring and Pacific Ocean during warm seasons (Steffen et al., 2008; Timonen et al., 2013). For the high GOM events in the present study, we did not observe clear evidence for the sources of GOM from the MBL over the Arctic region or the North Atlantic Ocean. Therefore, the oxidation of GEM in the free troposphere was likely the predominant source of high GOM at the PDM Observatory. The remaining 28 high GOM events (Table S3), with GOM poorly correlated with ozone and GEM concentrations, probably reflect the combined effect of intrusions of GOM-enriched air from middle and upper free troposphere, lower free troposphere over the Atlantic Ocean and mixing of boundary layer air over Europe during long-range transport.

\subsection{Seasonal trends of high PBM and GOM events}

The high PBM events were predominantly observed in winter and spring (from November to April, Fig. 7), which accounted for approximately $80 \%$ of the total high PBM events. In contrast, high GOM events were predominantly $(\sim 69 \%)$ observed in the summer and autumn (from May to October). The monthly variations in the frequencies of high PBM and GOM events were consistent with the monthly means of PBM and GOM concentrations, respectively. This is the first observation suggesting that high PBM and GOM events in the free troposphere in the middle latitude display distinct seasonal patterns ( $t$ test: $p<0.05)$.

ARTs related to the high PBM events in spring and winter showed maximum values in the upper free troposphere over North America (accounting for $35 \%$ of total high PBM ARTs), followed by the middle free troposphere over the North Atlantic Ocean (29\%), the upper free troposphere over the Arctic region (22\%) and the middle free troposphere over Europe (13\%; Fig. 8). The maximum high PBM ARTs over North America in spring and winter were partly attributed to increasing origins of air masses from this region under the influence of westerlies in the mid-latitude (Fig. 9). Additionally, the ratios of high PBM ARTs to total ARTs over North America were also elevated in winter and spring compared to summer and spring. It is noteworthy that the ratios of high PBM ARTs to total ARTs in winter and spring were significantly higher ( $t$ test, $p<0.05$ ) than that in summer and autumn over all the studied regions (Fig. 9). This result may imply that the middle and upper free troposphere of the Northern Hemisphere may be more enriched in PBM in spring and winter than in summer and autumn. This conclusion is consistent with the modeling result at low-altitude sites in North America which was likely due to cold season subsidence of PBM enriched air from the upper troposphere 

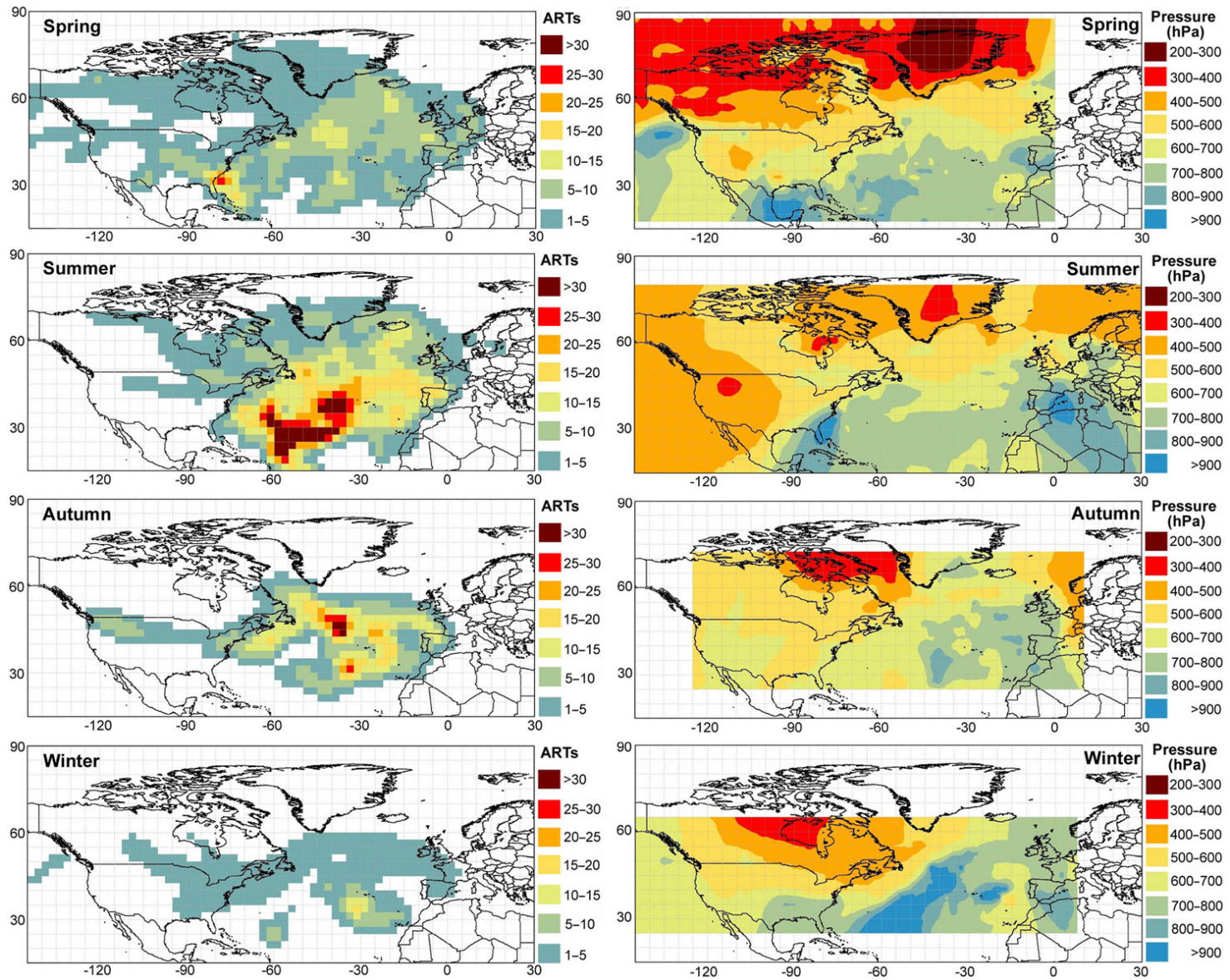

Figure 10. Air mass residence times (ARTs) and averaged pressure of air masses associated with high GOM events for each season during the study period.

and lower stratosphere (Amos et al., 2012). There are currently no observations regarding the seasonal trends of atmospheric PBM in the middle and upper free troposphere of the Northern Hemisphere. In spring and winter increasing PBM concentrations in the middle and upper free troposphere of the Northern Hemisphere are apparently in contrast with the lower atmospheric aerosol concentrations observed at the PDM Observatory as well as other high altitudes in Europe and North America (Browell et al., 2003; Asmi et al., 2011). We therefore proposed that factors other than atmospheric aerosols played a more important role in the seasonal variations of high PBM events at the PDM Observatory. As we discussed earlier, cold temperature and lower solar radiation may favor the production and accumulation of PBM in the free troposphere. Northern Hemisphere high latitudes are characterized by relatively lower air temperature and solar radiation during the cold season, which may facilitate the production and accumulation of PBM in the middle and upper troposphere in cold season and explain our seasonal variations in atmospheric PBM concentrations. In summer the highest high PBM ARTs were observed in the lower and mid- dle free troposphere over the North Atlantic Ocean (accounting for $72 \%$ of total ARTs in summer). The lower and middle free troposphere over the North Atlantic Ocean in summer produced many high GOM events (more details below), which are responsible for the highest ARTs associated with high PBM events in this region via gas-particle partitioning of atmospheric GOM.

ARTs related to the high GOM events showed maximum values over the North Atlantic Ocean regardless of seasons (accounting for $62-84 \%$ of total residence times). High GOM ARTs over the North Atlantic Ocean mainly correspond to the lower and middle free troposphere (Fig. 10). In summer when most of high GOM events were observed, high GOM ARTs showed maximum values in the lower free troposphere over the subtropical North Atlantic Ocean. Maximum high GOM ARTs were mainly observed in the middle free troposphere over the temperate and sub-arctic North Atlantic Ocean in spring and autumn (Figs. 10 and 11). The maximum high GOM ARTs over the subtropical North Atlantic Ocean in summer were partially attributed to frequent origins of air masses from this region (Fig. 11). Also, it is 


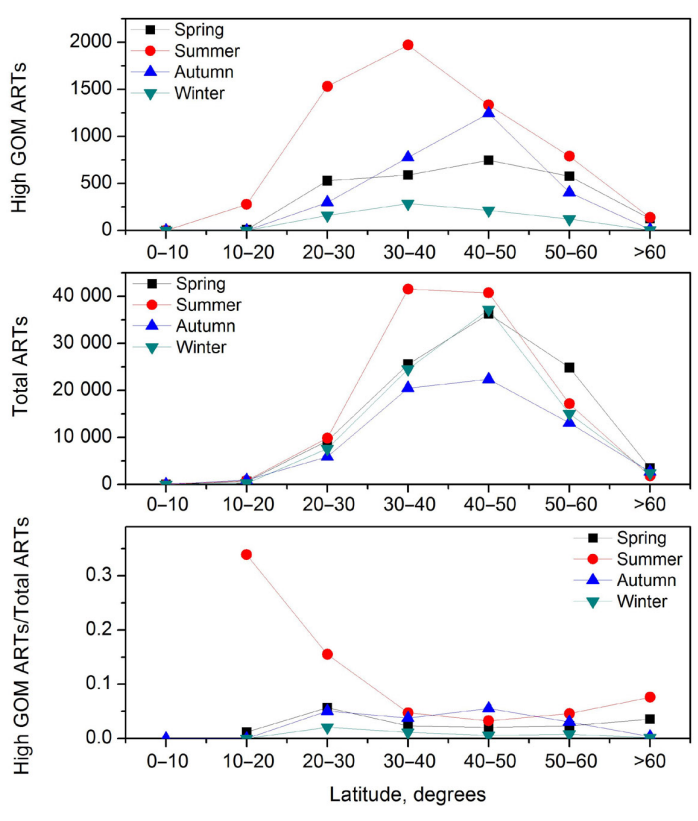

Figure 11. Latitude dependence of Air masses residence times (ARTs, top) associated with high GOM events, total residence times of all the air masses (Total ARTs, middle) and high GOM ARTs / Total ARTs ratios (bottom) over the North Atlantic Ocean for each season.

found that the ratios of high GOM ARTs to total ARTs over the subtropical North Atlantic Ocean in summer were up to an order of magnitude higher than that in other seasons over the temperate and sub-arctic North Atlantic Ocean in summer. These results imply that the lower free troposphere over the subtropical North Atlantic Ocean may be of specific significance for the production of GOM in summer. For other seasons, the maximum high GOM ARTs over the temperate and sub-arctic North Atlantic Ocean were related to frequent intrusions of air masses from the middle and upper free troposphere (Figs. 10 and 11).

The summer maximum high GOM events are also similar to observations at the Dead Sea, Israel (Moore et al., 2013), which were associated with elevated $\mathrm{BrO}$ concentrations in the MBL. Many recent studies also suggested that other oxidants such as hydroxyl radical $(\mathrm{OH})$, iodine oxides (IO), chlorine atoms $(\mathrm{Cl})$, ozone, nitrogen oxides (e.g. $\mathrm{NO}_{2}$ ) should be also involved in the production of GOM in the atmosphere (Dibble et al., 2012; Wang et al., 2014; WeissPenzias et al., 2015). Previous studies observed that OH, IO and $\mathrm{NO}_{2}$ concentrations in the MBL and lower free troposphere over the subtropical and tropical North Atlantic Ocean are highest in summer (Spivakovsky et al., 2000; Savage et al., 2004; Wang et al., 2014; Martin et al., 2008), which may explain the maximum summer high GOM ARTs in the lower free troposphere over the subtropical North Atlantic Ocean. On the other hand, atmospheric oxidants in the middle and upper free troposphere also display clear seasonal cycles. For instance, Fitzenberger et al. (2000) observed that $\mathrm{BrO}$ concentrations in the middle and upper free troposphere over the Arctic region were relatively higher in summer than in winter. Additionally, previous studies also suggested that tropospheric column ozone and $\mathrm{OH}$ concentrations in the Northern Hemisphere are highest in summer (Spivakovsky et al., 2000; Liu et al., 2006). These oxidants may favor the in situ production of GOM in the middle and upper free troposphere in summer.

\subsection{Potential source regions of PBM and GOM in different layers of troposphere}

The major potential source regions of PBM at the PDM Observatory were located over the temperate and sub-arctic North Atlantic Ocean and over Northwest Europe, whereas the major potential source regions of GOM at the PDM Observatory were located in the subtropical North Atlantic Ocean (Fig. 12). The PSCF analysis regarding the different atmospheric layers suggests that major source regions of PBM and GOM were both from the middle and upper free troposphere over the temperate and sub-arctic North Atlantic Ocean, Arctic region, North America, and Northwest Europe, which were followed by the lower free troposphere over the subtropical North Atlantic Ocean. On the other hand, the boundary layer over the Atlantic Ocean, Europe, and North America played a minimal role in the sources of PBM and GOM at the PDM Observatory. It should be pointed out that, owing to the trailing effect (areas upwind and downwind of actual source regions are likely identified as possible source regions), some of the identified source regions of PBM and GOM might be overestimated. As we discussed earlier, many high PBM and GOM events were related to air masses that originated from or traveled in the upper free troposphere over the Arctic region and sub-arctic North America. The transport of these air masses frequently took a southward route (Stohl et al., 2000), which may overestimate the contributions of source regions over the temperate and sub-arctic North Atlantic Ocean and Northwest Europe.

\section{Conclusions}

In the present study, we consider 1 full year of atmospheric $\mathrm{Hg}$ speciation observations at the high-altitude Pic du Midi (PDM) Observatory, located in the middle latitudes. Unlike previous studies at other high-altitude sites (mainly conducted in warm seasons or in the tropics), we observed multiple high PBM events (up to $98 \mathrm{pg} \mathrm{m}^{-3}$ ) in addition to multiple high GOM events (up to $295 \mathrm{pg} \mathrm{m}^{-3}$ ), which were mainly related to in situ atmospheric transformations. The seasonal variations in the occurrence of high PBM and GOM events were significantly different with most of the high PBM and GOM events occurring in cold seasons (winter and spring) and warm seasons (summer and autumn), respectively. Our 

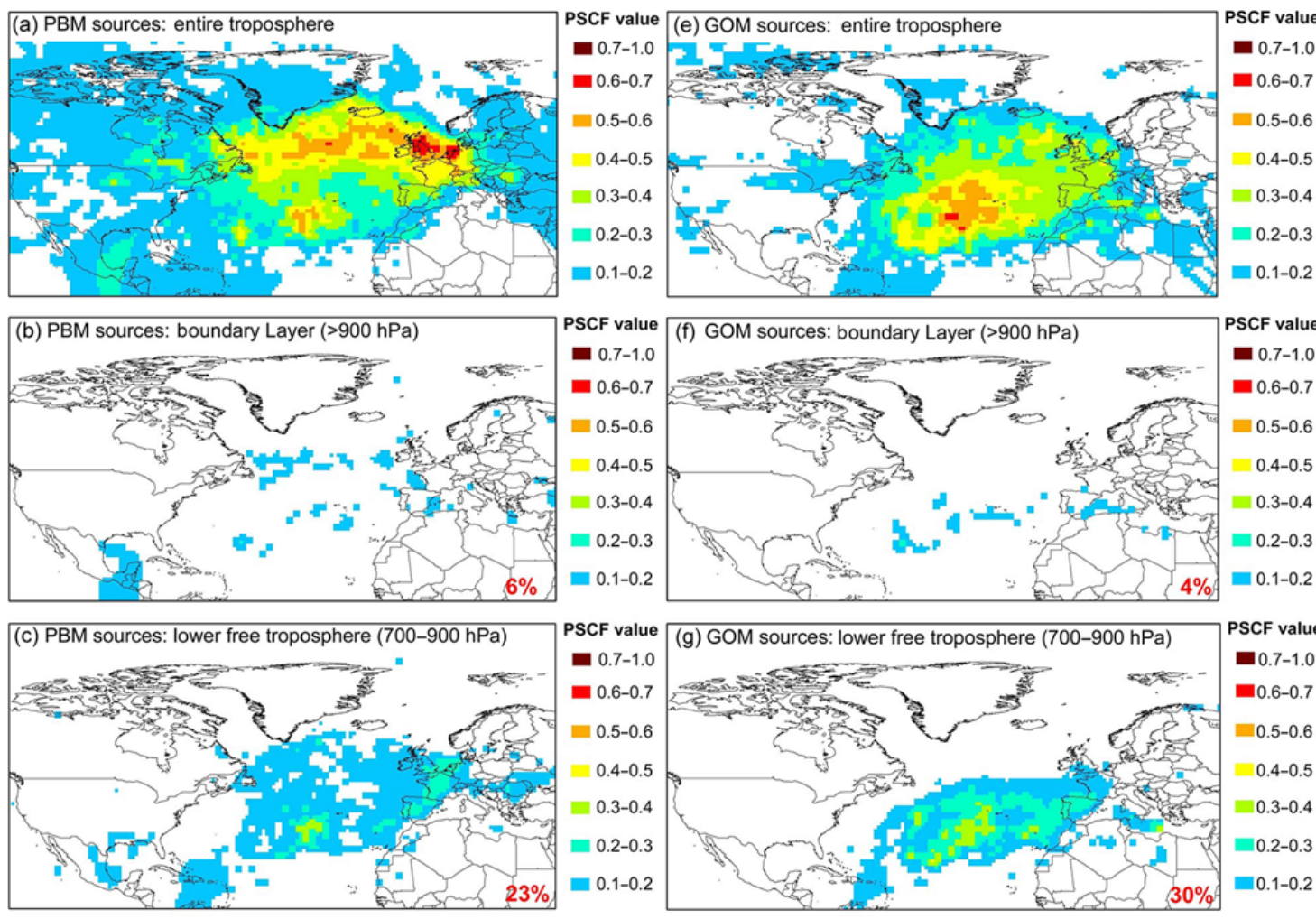

PSCF value

0.7-1.0

ㅁ. 0.6-0.7

0.5-0.6

0.4-0.5

0.3-0.4

-0.2-0.3

- $0.1-0.2$
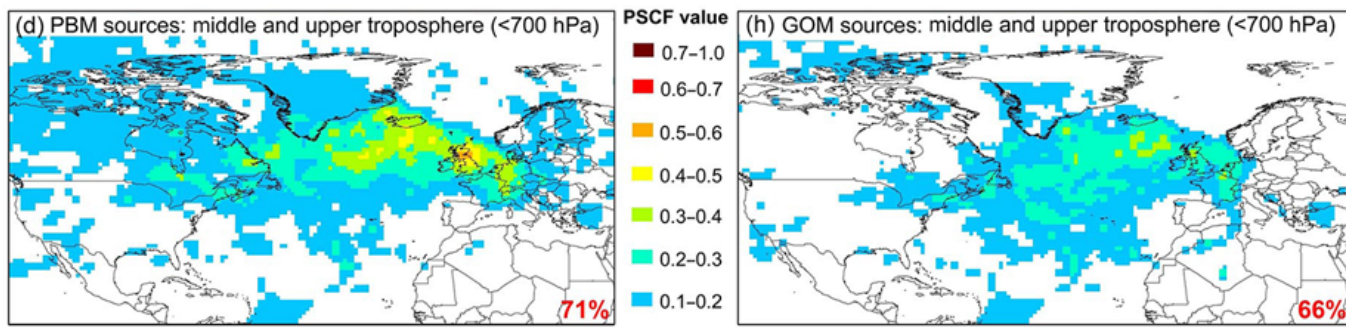

PSCF value
$0.7-1.0$
$0.6-0.7$
$0.5-0.6$
$0.4-0.5$
$0.3-0.4$
$0.2-0.3$
$0.1-0.2$

Figure 12. Map showing the identified potential source regions of PBM during the whole study period for (a) entire troposphere, (b) boundary layer, (c) lower free troposphere, and (d) middle and upper troposphere and potential source regions of GOM for (e) entire troposphere, (f) boundary layer, (g) lower free troposphere, and (g) middle and upper troposphere.

study suggests that an important fraction of depleted GEM is in the form of PBM in the middle and upper troposphere in cold seasons. These findings should be taken into account by modeling approaches to better understand the fate of $\mathrm{Hg}$ in the global atmosphere. Furthermore, our results suggest that the sources of high PBM and GOM events were also different. High PBM events in cold seasons were mainly related to intrusions from the upper troposphere over temperate and sub-arctic North American and Arctic regions as well as the middle troposphere over the temperate North Atlantic Ocean and Europe. On the other hand, high GOM events were attributed to in situ production in the middle and lower free troposphere over the subtropical North Atlantic Ocean. These seasonal and regional patterns may be caused by a combination of factors including variations of atmospheric oxidants and meteorological parameters (e.g. temperature and solar radiation). As GOM and PBM are readily deposited to Earth's surfaces, the frequent export of PBM- and GOMenriched air from North America, the Arctic region and the North Atlantic Ocean are expected to enhance wet and dry deposition and cause environmental risk of mercury in $\mathrm{Eu}-$ ropean ecosystems. This should be further evaluated using modeling approaches.

\section{Information about the Supplement}

Tables of the identified 44 high PBM events, 61 high GOM events and Pearson's correlation analysis between PBM and meteorological parameters and atmospheric pollutants are shown in Tables S1-S3.

Time series of atmospheric Hg speciation, backward trajectories of the 30 high PBM events related to upper tropo- 
spheric intrusions, backward trajectories of the six anthropogenic impacted high PBM events, backward trajectories of the eight mixed high PBM events, backward trajectories of the 24 high GOM events related to intrusions from middle and upper troposphere, backward trajectories of the nine high GOM events related to marine free tropospheric air are shown in Figs. S1-S6.

\section{The Supplement related to this article is available online at doi:10.5194/acp-16-5623-2016-supplement.}

Acknowledgements. This work was supported by research grant ERC-2010-StG_20091028 from the European Research Council and the National Science Foundation of China (41473025, 41273145). We acknowledge technical support from the UMS 831 Pic du Midi observatory team. Beyond mercury speciation, other observational data were provided by the PAES atmospheric monitoring service supported by CNRS-INSU.

Edited by: A. Dastoor

\section{References}

Amos, H. M., Jacob, D. J., Holmes, C. D., Fisher, J. A., Wang, Q., Yantosca, R. M., Corbitt, E. S., Galarneau, E., Rutter, A. P., Gustin, M. S., Steffen, A., Schauer, J. J., Graydon, J. A., Louis, V. L. St., Talbot, R. W., Edgerton, E. S., Zhang, Y., and Sunderland, E. M.: Gas-particle partitioning of atmospheric $\mathrm{Hg}$ (II) and its effect on global mercury deposition, Atmos. Chem. Phys., 12, 591-603, doi:10.5194/acp-12-591-2012, 2012.

Asmi, A., Wiedensohler, A., Laj, P., Fjaeraa, A.-M., Sellegri, K., Birmili, W., Weingartner, E., Baltensperger, U., Zdimal, V., Zikova, N., Putaud, J.-P., Marinoni, A., Tunved, P., Hansson, H.C., Fiebig, M., Kivekäs, N., Lihavainen, H., Asmi, E., Ulevicius, V., Aalto, P. P., Swietlicki, E., Kristensson, A., Mihalopoulos, N., Kalivitis, N., Kalapov, I., Kiss, G., de Leeuw, G., Henzing, B., Harrison, R. M., Beddows, D., O’Dowd, C., Jennings, S. G., Flentje, H., Weinhold, K., Meinhardt, F., Ries, L., and Kulmala, M.: Number size distributions and seasonality of submicron particles in Europe 2008-2009, Atmos. Chem. Phys., 11, 5505-5538, doi:10.5194/acp-11-5505-2011, 2011.

Bloss, W. J., Gravestock, T. J., Heard, D. E., Ingham, T., Johnson, G. P., and Lee, J. D.: Application of a compact all solid-state laser system to the in situ detection of atmospheric $\mathrm{OH}, \mathrm{HO} 2, \mathrm{NO}$ and IO by laser-induced fluorescence, J. Environ. Monitor., 5, 21-28, doi:10.1039/B208714f, 2003.

Browell, E. V., Hair, J. W., Butler, C. F., Grant, W. B., DeYoung, R. J., Fenn, M. A., Brackett, V. G., Clayton, M. B., Brasseur, L. A., Harper, D. B., Ridley, B. A., Klonecki, A. A., Hess, P. G., Emmons, L. K., Tie, X. X., Atlas, E. L., Cantrell, C. A., Wimmers, A. J., Blake, D. R., Coffey, M. T., Hannigan, J. W., Dibb, J. E., Talbot, R. W., Flocke, F., Weinheimer, A. J., Fried, A., Wert, B., Snow, J. A., and Lefer, B. L.: Ozone, aerosol, potential vorticity, and trace gas trends observed at high-latitudes over North America from February to May 2000, J. Geophys. Res.-Atmos., 108, D4, doi:10.1029/2001jd001390, 2003.

Brune, W. H., Faloona, I. C., Tan, D., Weinheimer, A. J., Campos, T., Ridley, B. A., Vay, S. A., Collins, J. E., Sachse, G. W., Jaegle, L., and Jacob, D. J.: Airborne in-situ $\mathrm{OH}$ and $\mathrm{HO}_{2}$ observations in the cloud-free troposphere and lower stratosphere during SUCCESS, Geophys. Res. Lett., 25, 1701-1704, doi:10.1029/97gl03098, 1998.

Carslaw, K. S., Peter, T., and Clegg, S. L.: Modeling the composition of liquid stratospheric aerosols, Rev. Geophys., 35, 125-154, doi:10.1029/97rg00078, 1997.

Cheng, I., Xu, X., and Zhang, L.: Overview of receptor-based source apportionment studies for speciated atmospheric mercury, Atmos. Chem. Phys., 15, 7877-7895, doi:10.5194/acp-15-78772015, 2015.

Chevalier, A., Gheusi, F., Delmas, R., Ordóñez, C., Sarrat, C., Zbinden, R., Thouret, V., Athier, G., and Cousin, J.-M.: Influence of altitude on ozone levels and variability in the lower troposphere: a ground-based study for western Europe over the period 2001-2004, Atmos. Chem. Phys., 7, 4311-4326, doi:10.5194/acp-7-4311-2007, 2007.

Cuevas, E., González, Y., Rodríguez, S., Guerra, J. C., GómezPeláez, A. J., Alonso-Pérez, S., Bustos, J., and Milford, C.: Assessment of atmospheric processes driving ozone variations in the subtropical North Atlantic free troposphere, Atmos. Chem. Phys., 13, 1973-1998, doi:10.5194/acp-13-1973-2013, 2013.

Dibble, T. S., Zelie, M. J., and Mao, H.: Thermodynamics of reactions of $\mathrm{ClHg}$ and $\mathrm{BrHg}$ radicals with atmospherically abundant free radicals, Atmos. Chem. Phys., 12, 10271-10279, doi:10.5194/acp-12-10271-2012, 2012.

Driscoll, C. T., Mason, R. P., Chan, H. M., Jacob, D. J., and Pirrone, N.: Mercury as a Global Pollutant: Sources, Pathways, and Effects, Environ. Sci. Technol., 47, 4967-4983, doi:10.1021/Es305071v, 2013.

Engström, A. and Magnusson, L.: Estimating trajectory uncertainties due to flow dependent errors in the atmospheric analysis, Atmos. Chem. Phys., 9, 8857-8867, doi:10.5194/acp-9-8857-2009, 2009.

Faïn, X., Obrist, D., Hallar, A. G., Mccubbin, I., and Rahn, T.: High levels of reactive gaseous mercury observed at a high elevation research laboratory in the Rocky Mountains, Atmos. Chem. Phys., 9, 8049-8060, doi:10.5194/acp-9-8049-2009, 2009.

Fitzenberger, R., Bosch, H., Camy-Peyret, C., Chipperfield, M. P., Harder, H., Platt, U., Sinnhuber, B. M., Wagner, T., and Pfeilsticker, K.: First profile measurements of tropospheric BrO, Geophys. Res. Lett., 27, 2921-2924, doi:10.1029/2000g1011531, 2000.

Fu, X., Feng, X., Sommar, J., and Wang, S.: A review of studies on atmospheric mercury in China, Sci. Total Environ., 421-422, 73-81, doi:10.1016/j.scitotenv.2011.09.089, 2012.

Fu, X. W., Feng, X. B., Qiu, G. L., Shang, L. H., and Zhang, H.: Speciated atmospheric mercury and its potential source in Guiyang, China, Atmos. Environ., 45, 4205-4212, doi:10.1016/j.atmosenv.2011.05.012, 2011.

Fu, X. W., Zhang, H., Yu, B., Wang, X., Lin, C.-J., and Feng, X. B.: Observations of atmospheric mercury in China: a critical review, Atmos. Chem. Phys., 15, 9455-9476, doi:10.5194/acp-15-94552015, 2015. 
Gao, R. S., Rosenlof, K. H., Fahey, D. W., Wennberg, P. O., Hintsa, E. J., and Hanisco, T. F.: OH in the tropical upper troposphere and its relationships to solar radiation and reactive nitrogen, J. Atmos. Chem., 71, 55-64, doi:10.1007/s10874-014-9280-2, 2014.

Gheusi, F., Ravetta, F., Delbarre, H., Tsamalis, C., Chevalier-Rosso, A., Leroy, C., Augustin, P., Delmas, R., Ancellet, G., Athier, G., Bouchou, P., Campistron, B., Cousin, J. M., Fourmentin, M., and Meyerfeld, Y.: Pic 2005, a field campaign to investigate lowtropospheric ozone variability in the Pyrenees, Atmos. Res., 101, 640-665, doi:10.1016/j.atmosres.2011.04.014, 2011.

Goodsite, M. E., Plane, J. M. C., and Skov, H.: A theoretical study of the oxidation of $\mathrm{Hg}-0$ to $\mathrm{HgBr}_{2}$ in the troposphere, Environ. Sci. Technol., 38, 1772-1776, doi:10.1021/Es034680s, 2004.

Gustin, M. S., Huang, J. Y., Miller, M. B., Peterson, C., Jaffe, D. A., Ambrose, J., Finley, B. D., Lyman, S. N., Call, K., Talbot, R., Feddersen, D., Mao, H. T., and Lindberg, S. E.: Do We Understand What the Mercury Speciation Instruments Are Actually Measuring? Results of RAMIX, Environ. Sci. Technol., 47, 7295-7306, doi:10.1021/Es3039104, 2013.

Henne, S., Brunner, D., Folini, D., Solberg, S., Klausen, J., and Buchmann, B.: Assessment of parameters describing representativeness of air quality in-situ measurement sites, Atmos. Chem. Phys., 10, 3561-3581, doi:10.5194/acp-10-3561-2010, 2010.

Holmes, C. D., Jacob, D. J., Corbitt, E. S., Mao, J., Yang, X., Talbot, R., and Slemr, F.: Global atmospheric model for mercury including oxidation by bromine atoms, Atmos. Chem. Phys., 10, 12037-12057, doi:10.5194/acp-10-12037-2010, 2010.

Huang, J. Y., Miller, M. B., Weiss-Penzias, P., and Gustin, M. S.: Comparison of Gaseous Oxidized $\mathrm{Hg}$ Measured by KCl-Coated Denuders, and Nylon and Cation Exchange Membranes, Environ. Sci. Technol., 47, 7307-7316, doi:10.1021/Es4012349, 2013.

Rolph, G. D.: Real-time Environmental Applications and Display System (READY) Website, NOAA Air Resources Laboratory, College Park, MD, available at: http://www.ready.noaa.gov (last access: 10 August 2015), 2016.

Kellerhals, M., Beauchamp, S., Belzer, W., Blanchard, P., Froude, F., Harvey, B., McDonald, K., Pilote, M., Poissant, L., Puckett, K., Schroeder, B., Steffen, A., and Tordon, R.: Temporal and spatial variability of total gaseous mercury in Canada: results from the Canadian Atmospheric Mercury Measurement Network (CAMNet), Atmos. Environ., 37, 1003-1011, doi:10.1016/S1352-2310(02)00917-2, 2003.

Kock, H. H., Bieber, E., Ebinghaus, R., Spain, T. G., and Thees, B.: Comparison of long-term trends and seasonal variations of atmospheric mercury concentrations at the two European coastal monitoring stations Mace Head, Ireland, and Zingst, Germany, Atmos. Environ., 39, 7549-7556, doi:10.1016/j.atmosenv.2005.02.059, 2005.

Kohler, M. O., Radel, G., Shine, K. P., Rogers, H. L., and Pyle, J. A.: Latitudinal variation of the effect of aviation NOx emissions on atmospheric ozone and methane and related climate metrics, Atmos. Environ., 64, 1-9, doi:10.1016/j.atmosenv.2012.09.013, 2013.

Lan, X., Talbot, R., Castro, M., Perry, K., and Luke, W.: Seasonal and diurnal variations of atmospheric mercury across the US determined from AMNet monitoring data, Atmos. Chem. Phys., 12, 10569-10582, doi:10.5194/acp-12-10569-2012, 2012.
Landis, M. S., Stevens, R. K., Schaedlich, F., and Prestbo, E. M.: Development and characterization of an annular denuder methodology for the measurement of divalent inorganic reactive gaseous mercury in ambient air, Environ. Sci. Technol., 36, 3000-3009, doi:10.1021/Es015887t, 2002.

Laurier, F. J. G., Mason, R. P., Whalin, L., and Kato, S.: Reactive gaseous mercury formation in the North Pacific Ocean's marine boundary layer: A potential role of halogen chemistry, J. Geophys. Res.-Atmos., 108, D17, doi:10.1029/2003jd003625, 2003.

Lee, D. S., Dollard, G. J., and Pepler, S.: Gas-phase mercury in the atmosphere of the United Kingdom, Atmos. Environ., 32, 855864, doi:10.1016/S1352-2310(97)00316-6, 1998.

Lee, D. S., Nemitz, E., Fowler, D., and Kingdon, R. D.: Modelling atmospheric mercury transport and deposition across Europe and the UK, Atmos. Environ., 35, 5455-5466, doi:10.1016/S13522310(01)00284-9, 2001.

Lin, C. J. and Pehkonen, S. O.: The chemistry of atmospheric mercury: a review, Atmos. Environ., 33, 2067-2079, doi:10.1016/S1352-2310(98)00387-2, 1999.

Lin, C.-J., Pan, L., Streets, D. G., Shetty, S. K., Jang, C., Feng, X., Chu, H.-W., and Ho, T. C.: Estimating mercury emission outflow from East Asia using CMAQ-Hg, Atmos. Chem. Phys., 10, 1853-1864, doi:10.5194/acp-10-1853-2010, 2010.

Lindberg, S., Bullock, R., Ebinghaus, R., Engstrom, D., Feng, X. B., Fitzgerald, W., Pirrone, N., Prestbo, E., and Seigneur, C.: A synthesis of progress and uncertainties in attributing the sources of mercury in deposition, Ambio, 36, 19-32, 2007.

Lindberg, S. E., Brooks, S., Lin, C. J., Scott, K. J., Landis, M. S., Stevens, R. K., Goodsite, M., and Richter, A.: Dynamic oxidation of gaseous mercury in the Arctic troposphere at polar sunrise, Environ. Sci. Technol., 36, 1245-1256, doi:10.1021/Es0111941, 2002.

Liu, X., Chance, K., Sioris, C. E., Kurosu, T. P., Spurr, R. J. D., Martin, R. V., Fu, T. M., Logan, J. A., Jacob, D. J., Palmer, P. I., Newchurch, M. J., Megretskaia, I. A., and Chatfield, R. B.: First directly retrieved global distribution of tropospheric column ozone from GOME: Comparison with the GEOS-CHEM model, J. Geophys. Res.-Atmos., 111, D02308, doi:10.1029/2005jd006564, 2006.

Lyman, S. N. and Jaffe, D. A.: Formation and fate of oxidized mercury in the upper troposphere and lower stratosphere, Nat. Geosci., 5, 114-117, doi:10.1038/Ngeo1353, 2012.

Lyman, S. N., Jaffe, D. A., and Gustin, M. S.: Release of mercury halides from $\mathrm{KCl}$ denuders in the presence of ozone, Atmos. Chem. Phys., 10, 8197-8204, doi:10.5194/acp-10-81972010, 2010.

Malcolm, E. G. and Keeler, G. J.: Evidence for a sampling artifact for particulate-phase mercury in the marine atmosphere, Atmos. Environ., 41, 3352-3359, doi:10.1016/j.atmosenv.2006.12.024, 2007.

Manolopoulos, H., Snyder, D. C., Schauer, J. J., Hill, J. S., Turner, J. R., Olson, M. L., and Krabbenhoft, D. P.: Sources of speciated atmospheric mercury at a residential neighborhood impacted by industrial sources, Environ. Sci. Technol., 41, 56265633, doi:10.1021/Es0700348, 2007.

Martin, M. V., Honrath, R. E., Owen, R. C., and Li, Q. B.: Seasonal variation of nitrogen oxides in the central North Atlantic lower free troposphere, J. Geophys. Res.-Atmos., 113, D17307, doi:10.1029/2007jd009688, 2008. 
McClure, C. D., Jaffe, D. A., and Edgerton, E. S.: Evaluation of the KCI Denuder Method for Gaseous Oxidized Mercury using $\mathrm{HgBr}_{2}$ at an In-Service AMNet Site, Environ. Sci. Technol., 48, 11437-11444, doi:10.1021/Es502545k, 2014.

Michelsen, H. A., Spivakovsky, C. M., and Wofsy, S. C.: Aerosolmediated partitioning of stratospheric $\mathrm{Cl}-\mathrm{y}$ and NOy at temperatures above $200 \mathrm{~K}$, Geophys. Res. Lett., 26, 299-302, doi:10.1029/1998g1900281, 1999.

Moore, C. W., Obrist, D., and Luria, M.: Atmospheric mercury depletion events at the Dead Sea: Spatial and temporal aspects, Atmos. Environ., 69, 231-239, doi:10.1016/j.atmosenv.2012.12.020, 2013.

Murphy, D. M., Thomson, D. S., and Mahoney, T. M. J.: In situ measurements of organics, meteoritic material, mercury, and other elements in aerosols at 5 to 19 kilometers, Science, 282, 16641669, doi:10.1126/science.282.5394.1664, 1998.

Murphy, D. M., Hudson, P. K., Thomson, D. S., Sheridan, P. J., and Wilson, J. C.: Observations of mercury-containing aerosols, Environ. Sci. Technol., 40, 3163-3167, doi:10.1021/Es052385x, 2006.

Obrist, D., Moosmuller, H., Schurmann, R., Chen, L. W. A., and Kreidenweis, S. M.: Particulate-phase and gaseous elemental mercury emissions during biomass combustion: Controlling factors and correlation with particulate matter emissions, Environ. Sci. Technol., 42, 721-727, doi:10.1021/Es071279n, 2008.

Obrist, D., Tas, E., Peleg, M., Matveev, V., Fain, X., Asaf, D., and Luria, M.: Bromine-induced oxidation of mercury in the mid-latitude atmosphere, Nat. Geosci., 4, 22-26, doi:10.1038/Ngeo1018, 2011.

Pirrone, N., Cinnirella, S., Feng, X., Finkelman, R. B., Friedli, H. R., Leaner, J., Mason, R., Mukherjee, A. B., Stracher, G. B., Streets, D. G., and Telmer, K.: Global mercury emissions to the atmosphere from anthropogenic and natural sources, Atmos. Chem. Phys., 10, 5951-5964, doi:10.5194/acp-10-59512010, 2010.

Poirot, R. L. and Wishinski, P. R.: Visibility, Sulfate and Air-Mass History Associated with the Summertime Aerosol in Northern Vermont, Atmos. Environ., 20, 1457-1469, doi:10.1016/00046981(86)90018-1, 1986.

Polissar, A. V., Hopke, P. K., and Harris, J. M.: Source regions for atmospheric aerosol measured at Barrow, Alaska, Environ. Sci. Technol., 35, 4214-4226, doi:10.1021/Es0107529, 2001.

Read, K. A., Mahajan, A. S., Carpenter, L. J., Evans, M. J., Faria, B. V. E., Heard, D. E., Hopkins, J. R., Lee, J. D., Moller, S. J., Lewis, A. C., Mendes, L., McQuaid, J. B., Oetjen, H., Saiz-Lopez, A., Pilling, M. J., and Plane, J. M. C.: Extensive halogen-mediated ozone destruction over the tropical Atlantic Ocean, Nature, 453, 1232-1235, doi:10.1038/Nature07035, 2008.

Rutter, A. P. and Schauer, J. J.: The effect of temperature on the gas-particle partitioning of reactive mercury in atmospheric aerosols, Atmos. Environ., 41, 8647-8657, doi:10.1016/j.atmosenv.2007.07.024, 2007.

Savage, N. H., Law, K. S., Pyle, J. A., Richter, A., Nüß, H., and Burrows, J. P.: Using GOME $\mathrm{NO}_{2}$ satellite data to examine regional differences in TOMCAT model performance, Atmos. Chem. Phys., 4, 1895-1912, doi:10.5194/acp-4-1895-2004, 2004.
Schroeder, W. H. and Munthe, J.: Atmospheric mercury - An overview, Atmos. Environ., 32, 809-822, doi:10.1016/S13522310(97)00293-8, 1998.

Selin, N. E., Jacob, D. J., Park, R. J., Yantosca, R. M., Strode, S., Jaegle, L., and Jaffe, D.: Chemical cycling and deposition of atmospheric mercury: Global constraints from observations, J. Geophys. Res.-Atmos., 112, D02308, doi:10.1029/2006jd007450, 2007.

Selin, N. E., Jacob, D. J., Yantosca, R. M., Strode, S., Jaegle, L., and Sunderland, E. M.: Global 3-D land-ocean-atmosphere model for mercury: Present-day versus preindustrial cycles and anthropogenic enrichment factors for deposition, Global Biogeochem. Cy., 22, Gb2011, 10.1029/2007gb003040, 2008.

Sexauer Gustin, M., Weiss-Penzias, P. S., and Peterson, C.: Investigating sources of gaseous oxidized mercury in dry deposition at three sites across Florida, USA, Atmos. Chem. Phys., 12, 92019219, doi:10.5194/acp-12-9201-2012, 2012.

Sheu, G. R., Lin, N. H., Wang, J. L., Lee, C. T., Yang, C. F. O., and Wang, S. H.: Temporal distribution and potential sources of atmospheric mercury measured at a high-elevation background station in Taiwan, Atmos. Environ., 44, 2393-2400, doi:10.1016/j.atmosenv.2010.04.009, 2010.

Slemr, F. and Scheel, H. E.: Trends in atmospheric mercury concentrations at the summit of the Wank mountain, southern Germany, Atmos. Environ., 32, 845-853, doi:10.1016/S13522310(97)00131-3, 1998.

Slemr, F., Ebinghaus, R., Brenninkmeijer, C. A. M., Hermann, M., Kock, H. H., Martinsson, B. G., Schuck, T., Sprung, D., van Velthoven, P., Zahn, A., and Ziereis, H.: Gaseous mercury distribution in the upper troposphere and lower stratosphere observed onboard the CARIBIC passenger aircraft, Atmos. Chem. Phys., 9, 1957-1969, doi:10.5194/acp-9-1957-2009, 2009.

Slemr, F., Weigelt, A., Ebinghaus, R., Brenninkmeijer, C., Baker, A., Schuck, T., Rauthe-Schoch, A., Riede, H., Leedham, E., Hermann, M., van Velthoven, P., Oram, D., O’Sullivan, D., Dyroff, C., Zahn, A., and Ziereis, H.: Mercury Plumes in the Global Upper Troposphere Observed during Flights with the CARIBIC Observatory from May 2005 until June 2013, Atmosphere-Basel, 5, 342-369, doi:10.3390/Atmos5020342, 2014.

Slemr, F., Weigelt, A., Ebinghaus, R., Kock, H. H., Bödewadt, J., Brenninkmeijer, C. A. M., Rauthe-Schöch, A., Weber, S., Hermann, M., Zahn, A., and Martinsson, B.: Atmospheric mercury measurements onboard the CARIBIC passenger aircraft, Atmos. Meas. Tech. Discuss., doi:10.5194/amt-2015-376, in review, 2016.

Song, X. J., Cheng, I., and Lu, J.: Annual atmospheric mercury species in Downtown Toronto, Canada, J. Environ. Monitor., 11, 660-669, doi:10.1039/B815435j, 2009.

Spivakovsky, C. M., Logan, J. A., Montzka, S. A., Balkanski, Y. J., Foreman-Fowler, M., Jones, D. B. A., Horowitz, L. W., Fusco, A. C., Brenninkmeijer, C. A. M., Prather, M. J., Wofsy, S. C., and McElroy, M. B.: Three-dimensional climatological distribution of tropospheric OH: Update and evaluation, J. Geophys. Res.Atmos., 105, 8931-8980, doi:10.1029/1999jd901006, 2000.

Sprovieri, F., Pirrone, N., Landis, M. S., and Stevens, R. K.: Oxidation of gaseous elemental mercury to gaseous divalent mercury during 2003 polar sunrise at Ny-Alesund, Environ. Sci. Technol., 39, 9156-9165, doi:10.1021/Es050965o, 2005. 
Sprovieri, F., Pirrone, N., Ebinghaus, R., Kock, H., and Dommergue, A.: A review of worldwide atmospheric mercury measurements, Atmos. Chem. Phys., 10, 8245-8265, doi:10.5194/acp10-8245-2010, 2010.

Steffen, A., Douglas, T., Amyot, M., Ariya, P., Aspmo, K., Berg, T., Bottenheim, J., Brooks, S., Cobbett, F., Dastoor, A., Dommergue, A., Ebinghaus, R., Ferrari, C., Gardfeldt, K., Goodsite, M. E., Lean, D., Poulain, A. J., Scherz, C., Skov, H., Sommar, J., and Temme, C.: A synthesis of atmospheric mercury depletion event chemistry in the atmosphere and snow, Atmos. Chem. Phys., 8, 1445-1482, doi:10.5194/acp-8-1445-2008, 2008.

Steffen, A., Scherz, T., Olson, M., Gay, D., and Blanchard, P.: A comparison of data quality control protocols for atmospheric mercury speciation measurements, J. Environ. Monitor., 14, 752765, doi:10.1039/c2em10735j, 2012.

Stohl, A., Spichtinger-Rakowsky, N., Bonasoni, P., Feldmann, H., Memmesheimer, M., Scheel, H. E., Trickl, T., Hubener, S., Ringer, W., and Mandl, M.: The influence of stratospheric intrusions on alpine ozone concentrations, Atmos. Environ., 34, 1323-1354, doi:10.1016/S1352-2310(99)00320-9, 2000.

Stohl, A., Forster, C., Frank, A., Seibert, P., and Wotawa, G.: Technical note: The Lagrangian particle dispersion model FLEXPART version 6.2, Atmos. Chem. Phys., 5, 2461-2474, doi:10.5194/acp-5-2461-2005, 2005.

Subir, M., Ariya, P. A., and Dastoor, A. P.: A review of the sources of uncertainties in atmospheric mercury modeling II, Mercury surface and heterogeneous chemistry - A missing link, Atmos. Environ., 46, 1-10, doi:10.1016/j.atmosenv.2011.07.047, 2012.

Swartzendruber, P. C., Jaffe, D. A., Prestbo, E. M., Weiss-Penzias, P., Selin, N. E., Park, R., Jacob, D. J., Strode, S., and Jaegle, L.: Observations of reactive gaseous mercury in the free troposphere at the Mount Bachelor Observatory, J. Geophys. Res.-Atmos., 111, D24302, doi:10.1029/2006jd007415, 2006.

Swartzendruber, P. C., Jaffe, D. A., and Finley, B.: Improved fluorescence peak integration in the Tekran 2537 for applications with sub-optimal sample loadings, Atmos. Environ., 43, 36483651, doi:10.1016/j.atmosenv.2009.02.063, 2009.
Talbot, R., Mao, H., Scheuer, E., Dibb, J., and Avery, M.: Total depletion of $\mathrm{Hg}$ degrees in the upper tropospherelower stratosphere, Geophys. Res. Lett., 34, L23804, doi:10.1029/2007g1031366, 2007.

Timonen, H., Ambrose, J. L., and Jaffe, D. A.: Oxidation of elemental $\mathrm{Hg}$ in anthropogenic and marine airmasses, Atmos. Chem. Phys., 13, 2827-2836, doi:10.5194/acp-13-2827-2013, 2013.

Tsamalis, C., Ravetta, F., Gheusi, F., Delbarre, H., and Augustin, P.: Mixing of free-tropospheric air with the lowland boundary layer during anabatic transport to a high altitude station, Atmos. Res., 143, 425-437, doi:10.1016/j.atmosres.2014.03.011, 2014.

Wang, F., Saiz-Lopez, A., Mahajan, A. S., Gómez Martín, J. C. Armstrong, D., Lemes, M., Hay, T., and Prados-Roman, C.: Enhanced production of oxidised mercury over the tropical Pacific Ocean: a key missing oxidation pathway, Atmos. Chem. Phys., 14, 1323-1335, doi:10.5194/acp-14-1323-2014, 2014.

Weiss-Penzias, P., Amos, H. M., Selin, N. E., Gustin, M. S., Jaffe, D. A., Obrist, D., Sheu, G.-R., and Giang, A.: Corrigendum to "Use of a global model to understand speciated atmospheric mercury observations at five high-elevation sites" published in Atmos. Chem. Phys., 15, 1161-1173, 2015, Atmos. Chem. Phys., 15, 2225-2225, doi:10.5194/acp-15-2225-2015, 2015.

Zeng, Y. and Hopke, P. K.: A Study of the Sources of Acid Precipitation in Ontario, Canada, Atmos. Environ., 23, 1499-1509, doi:10.1016/0004-6981(89)90409-5, 1989.

Zhang, L. M., Wright, L. P., and Blanchard, P.: A review of current knowledge concerning dry deposition of atmospheric mercury, Atmos. Environ., 43, 5853-5864, doi:10.1016/j.atmosenv.2009.08.019, 2009. 